\title{
Awards Program of the American Dairy Science Association
}

The annual Awards Program of the American Dairy Science Association and installation of new officers was held on July 14, 2009, at the Palais de Congrès, Montréal, Quebec, Canada. Past President MaryAnne Drake read the citations, and representatives of the donors presented the awards. The association greatly appreciates the continued generosity and support of the donors in presenting the annual awards to ADSA members.

\section{Citation for Geoffrey Zanton Recipient of the 2009 Alltech Inc. Graduate Student Paper Publication Award}

The recipient of the 2009 Alltech Inc. Graduate Student Paper Publication Award is Geoffrey I. Zanton, awarded for a paper published on his $\mathrm{PhD}$ research

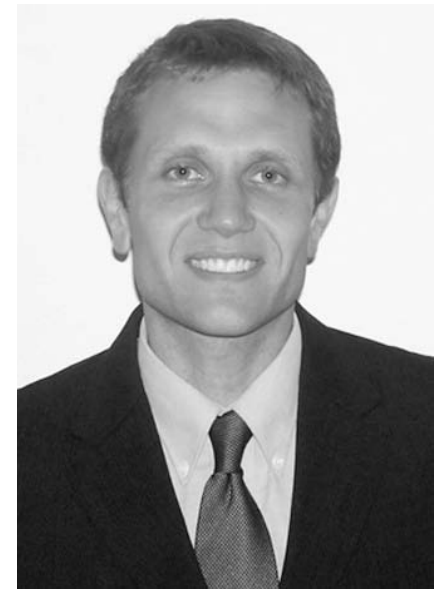
at Penn State University. "Analysis of nitrogen utilization and excretion in growing dairy cattle" was published in the April 2008 issue of the Journal of Dairy Science. The paper used a mixed modeling and fixed regression approach to characterize the effect of additional dietary nitrogen on nitrogen utilization and excretion in growing heifers using individual animal data from 16 published papers. This analysis determined a dietary crude protein concentration and protein-to-energy ratio for milk-fed calves and weaned heifers that maximized efficiency of nitrogen use. The paper provided a robust analysis of protein utilization at different stages of growth and under diverse dietary conditions. Zanton's work provides essential data for balancing heifer diets that reduce the cost of raising dairy heifers and minimize nitrogen excretion, thus improving whole-farm profitability and environmental sustainability. Zanton has previously published a meta-analysis of the effect of prepubertal heifer growth rate on subsequent milk production and

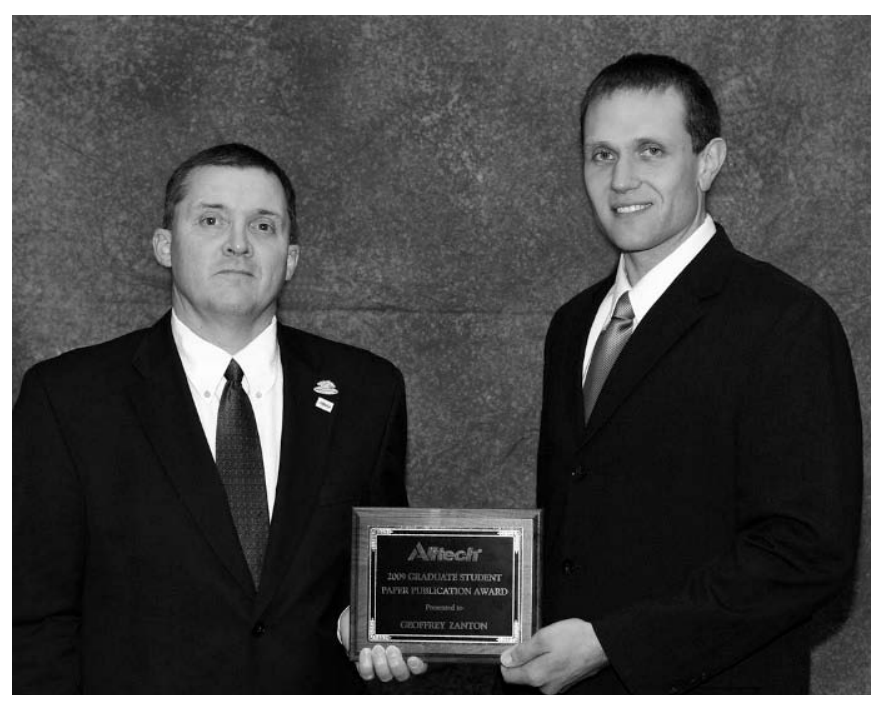

Geoffrey Zanton (right) receives the 2009 Alltech Inc. Student Paper Publication Award from Alan Harrison, donor representative (left).

an evaluation of in situ digestibility modeling procedures in the Journal of Dairy Science and the Journal of Animal Science.

Zanton was raised on a dairy and crop farm in southcentral Wisconsin and had a strong interest in agriculture from an early age. He received a BS degree in animal science with a business focus in 2000 and a BS in dairy science with a natural science focus in 2002, both from the University of Wisconsin at Madison. In 2008, he received his PhD in dairy and animal science with a minor in statistics from Penn State University under the direction of A. J. Heinrichs. His PhD research focused on novel high-concentrate, limit-feeding strategies for dairy heifers. This approach reduces the amount of farm-raised feedstuff required for heifers and reduces manure excretion. This research spanned investigations of nutrition, growth and development, and milk production. Zanton is an author on 10 peer-reviewed articles, 11 popular press and conference proceedings articles, and 15 conference abstracts.

Zanton is currently a postdoctoral fellow at Penn State University and a member of ADSA, the American Society of Animal Science, the American Society for Nutritional Science, and the American Statistical Association. 


\section{Citation for Limin Kung Jr. Recipient of the 2009 American Feed Industry Association Award}

Limin Kung Jr. is currently a professor at the University of Delaware with a $60 \%$ research, $25 \%$ teaching, and $15 \%$ extension appointment. Kung received his

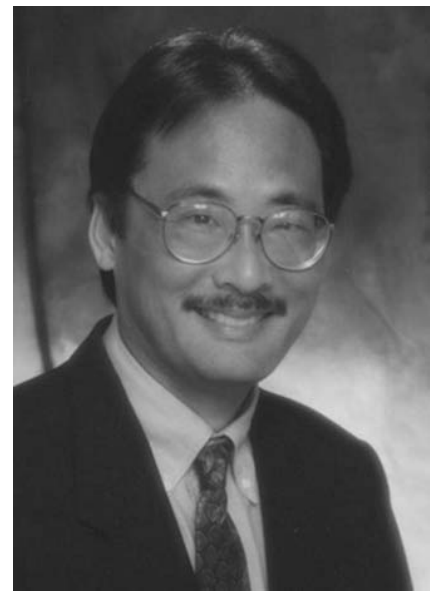

BS and MS degrees from the University of Hawaii and his $\mathrm{PhD}$ degree from Michigan State University.

Kung is recognized nationally and internationally for his outstanding research contributions to the dairy industry. He has constantly striven to conduct timely and applicable research to improve the efficiency of production and increase net farm income on dairy farms. Kung is recognized for his research contributions in the areas of rumen metabolism and forage quality. Most notably, Kung's research was crucial in gaining approval for the use of Lactobacillus buchneri (approved by the FDA in 2001) added to silages. This is the only bacterium that has been added to the original list of organisms approved for use in silage additives. His research played a pivotal role in the claim for improved aerobic stability with $L$. buchneri because it is the only silage inoculant approved by the FDA (2003) to legally make this claim. His research group also showed that with drier forages, use of a liquid-applied inoculant is more effective in improving silage fermentation than a similar formulation applied in a dry form because lack of sufficient water activity in dry forages limits the growth of added bacteria. This has resulted in increased use of liquid-applied inoculants. In addition, his group documented that the viability of some microbial inoculants is greatly compromised if the temperature of the water mix becomes too hot. Thus, many producers are now checking water temperatures in tanks to ensure the inoculants remain viable.

Kung's group has also focused on timely research topics including high cutting corn silage, use of BMR corn silage, and the use of oxygen-barrier plastics for covering bunker silos and has made significant contributions in other areas of dairy nutrition. For example, his group conducted some of the first lactation trials on directly adding enzymes to total mixed rations and the use of essential oils for lactating dairy cows. Furthermore, Kung's early pioneering research on inhibiting

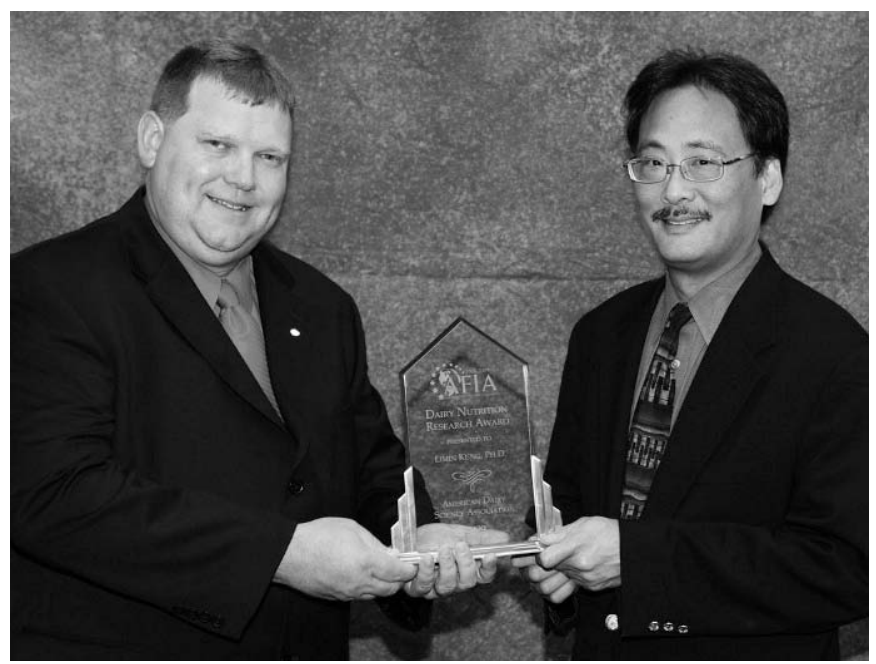

Limin Kung Jr. (right) receives the 2009 American Feed Industry Association Award from Clay Zimmerman, donor representative (left).

sulfide production in the rumen is currently a topic of renewed interest because of high-sulfate water and the increased use of distillers grains. Since 1999, Kung and colleagues have published their research findings in 32 peer-reviewed articles and have presented 49 research abstracts at major meetings. Kung also had three book chapters published in the same time frame as well as numerous articles in the popular press and extension newsletters. In the last 10 years, Kung has made over 400 invited presentations in 28 states and 77 presentations in 11 other countries.

Limin Kung Jr. is a deserving candidate for the ADSA American Feed Industry Award because of his excellence in research and his dedication to helping the dairy industry in solving important problems.

\section{Citation for Masahito Oba \\ Recipient of the 2009 Cargill Animal Nutrition Young Scientist Award}

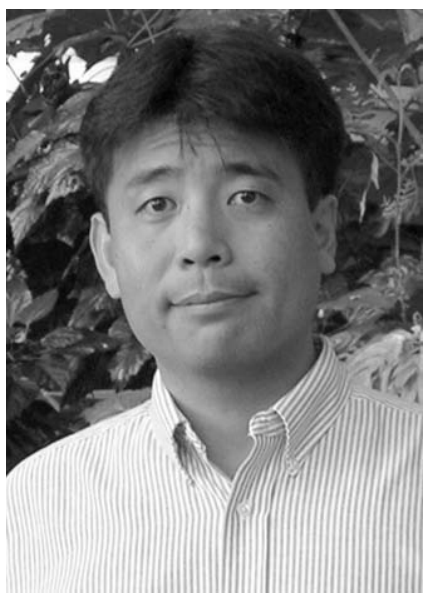

The recipient of the 2009 Cargill Animal Nutrition Young Scientist Award is Masahito Oba, associate professor of dairy nutrition in the Department of Agricultural, Food, and Nutritional Science at the University of Alberta, Edmonton, Canada. Oba earned his BS from Iowa State University in 1995 and his $\mathrm{MS}$ and $\mathrm{PhD}$ from Michigan State University 
in 1998 and 2002, respectively. Following a postdoctoral fellowship at the University of Maryland, Oba was appointed assistant professor of dairy nutrition at the University of Alberta in 2004 and was promoted to associate professor in 2008.

During the past five years, Oba has established a highly productive and innovative research program at the University of Alberta. His major work has been in the area of ruminal carbohydrate metabolism, with specific focus on effects of processing and type of barley grain on fermentability, digestibility, and performance of dairy cows. He has also produced timothy hay with a low dietary cation-anion difference (DCAD) through fertilization with calcium chloride and determined that feeding this low-DCAD hay to dry cows can prevent hypocalcemia. More recently, he reported that changing the forage-to-concentrate ratio in diets fed to dairy cows causes changes in energy metabolism of ruminal epithelial tissues through altered expression of genes. He has been an active researcher in the area of fat and fatty acid nutrition from various feed sources and their role in reproduction and milk fat composition.

Masahito Oba has amassed a remarkable publication record for an early-career scientist. He has authored or coauthored 37 peer-reviewed journal papers, 73 abstracts for scientific meetings, 9 conference proceedings papers, and more than 100 popular press articles in the area of dairy cattle nutrition. He has finished the training of four MSc students and one $\mathrm{PhD}$ student during the past five years and is currently supervising six MSc students. Since 2005, he has secured external research funding of more than $\$ 2.0$ million as principal investigator and $\$ 4.7$ million as a co-investigator.

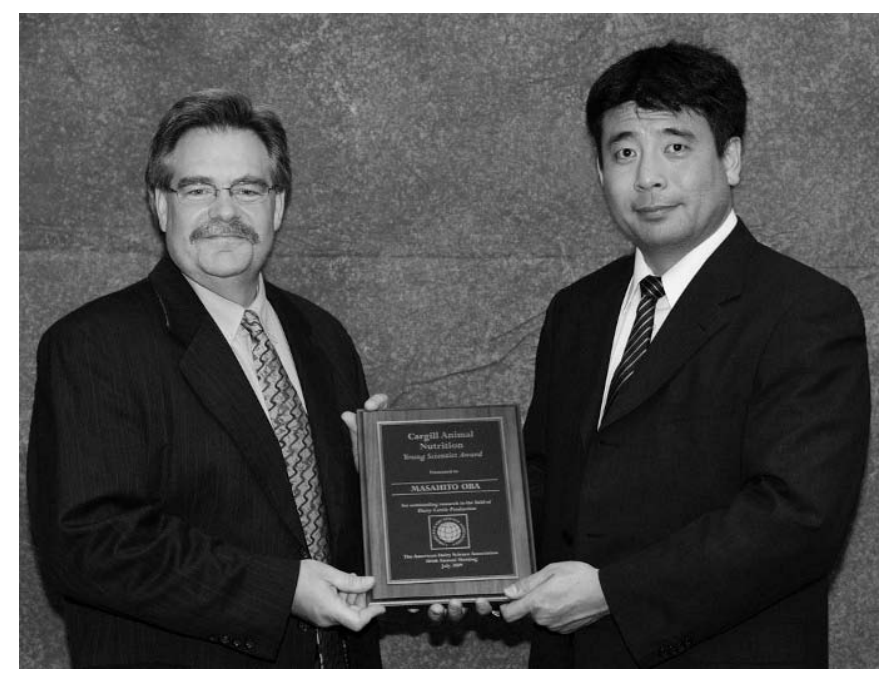

Masahito Oba (right) receives the 2009 Cargill Animal Nutrition Young Scientist Award from Mike Jerred, donor representative (left).
In addition to being a highly prolific researcher, Oba excels in the classroom. He teaches courses in metabolic physiology and ruminant nutrition and metabolism at the undergraduate level and advanced animal metabolism and advanced feed science and technology at the graduate level. He was awarded the Teacher of the Year Award by the Faculty of Agriculture, Forestry, and Home Economics at the University of Alberta in 2006 and 2007 and the Agriculture Club Teaching Award in 2006.

Oba is also committed to seeing science translated into practical outcomes. He has maintained an active industry outreach component to his program as an invited speaker at various extension events in Alberta, and he remains committed to helping foster innovation in the dairy industry of his native country of Japan through speaking tours and by working with various Japanese dairy cooperatives.

\section{Citation for Lloyd Metzger Recipient of the 2009 Cargill Flavor Systems Food Specialties Award}

Lloyd Metzger, associate professor and Alfred Chair of Dairy Education at South Dakota State University, is the recipient of the 2009 Cargill Flavor Systems Food Specialties Award. Metzger grew up on a dairy farm in northwest Iowa and obtained his BS degree in dairy

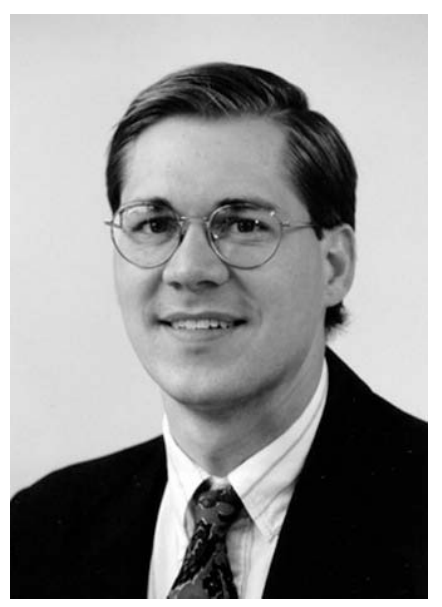
manufacturing and his MS degree in dairy science from South Dakota State University and his $\mathrm{PhD}$ in food science from Cornell University. After completing his $\mathrm{PhD}$, he spent two years as a research scientist at General Mills, where he received the General Mills Bell Achievement Award for Discovery in 1999. In July 2000, Metzger became an assistant professor in the Department of Food Science and Nutrition at the University of Minnesota. In July 2006, he was promoted to associate professor and received tenure. In January 2007, he joined South Dakota State University. Metzger has also served as the director of the Midwest Dairy Foods Research Center since January 2003 and currently serves as the executive secretary of the North Central Cheese Industries Association. His research interests include evaluating the structural and functional roles of the various components in cheese and fermented dairy products and developing modified 


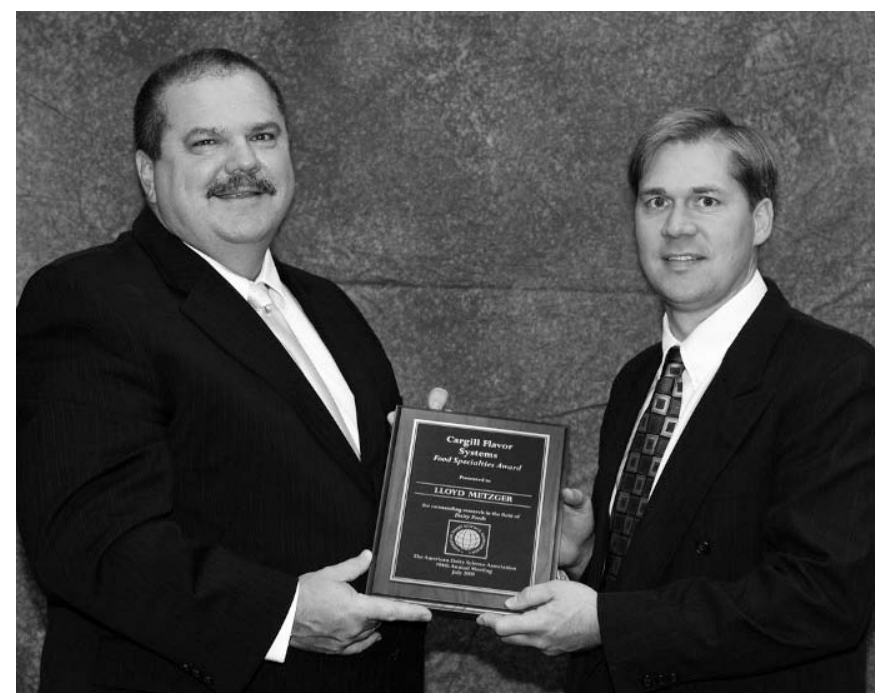

Lloyd Metzger (right) receives the 2009 Cargill Flavor Systems Food Specialties Award William Aimutis, donor representative (left).

manufacturing parameters to control cheese quality. Metzger has over 30 refereed scientific publications, 6 patents, and 3 patent applications. He was the recipient of the ADSA Foundation Scholar Award in 2005.

Lloyd Metzger received the Cargill Flavor Systems Food Specialties Award based on his research on the manufacturing of cottage cheese in an enclosed vat and development of a technique for prevention of calcium lactate crystals in Cheddar cheese. His research on cottage cheese and calcium lactate crystal prevention in Cheddar cheese has been commercialized and has had a significant effect on the processing efficiency and quality of these cheeses.

Prior to Metzger's research, large-scale production of cottage cheese in an automated enclosed vat was not possible, and the typical cottage cheese manufacturing process used an open-vat process that was labor intensive and did not utilize a clean-in-place cleaning system. In his research, Metzger developed a cooking procedure that removed whey from the vat, heated it to the desired temperature, and returned it to the vat. This process was critical and allowed the fragile curd to be cooked without causing excessive curd damage.

Before Metzger's research on calcium lactate crystals in Cheddar cheese, numerous factors influencing the formation of calcium lactate crystals were identified and extensively studied. However, this defect remained prevalent in Cheddar cheese. In his research, Metzger developed a process to utilize a GRAS ingredient called sodium gluconate, which is added to the cheese during the salting step of the manufacturing process. In the cheese, sodium gluconate prevents the formation of calcium lactate crystals by forming complexes with calcium lactate. These complexes cause a substantial increase in the solubility of calcium lactate and prevent formation of calcium lactate crystals in the cheese during ripening and distribution.

\section{Citation for Alan L. Kelly Recipient of the 2009 Danisco International Dairy Science Award}

The 2009 winner of the Danisco International Dairy Science Award is Alan Kelly, professor in the Department of Food and Nutritional Sciences at Univer-

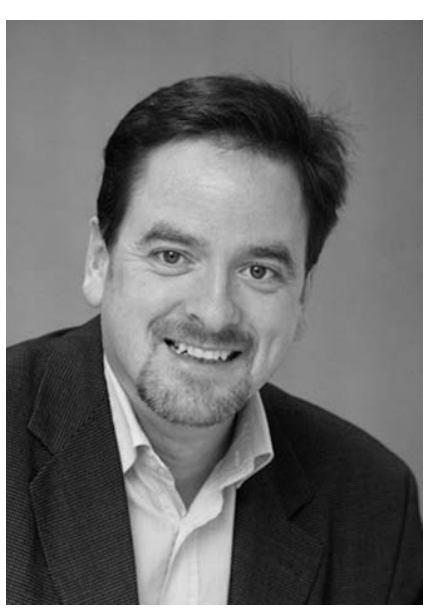
sity College Cork, Ireland. Kelly obtained his BS degree in biotechnology from Dublin City University and his $\mathrm{PhD}$ in food technology from University College Cork. Kelly leads an active research group on the chemistry and processing of milk and dairy products, has published over 150 research papers, review articles, and book chapters, and has supervised over $25 \mathrm{MSc}$ and $\mathrm{PhD}$ students. His research involves many national and international collaborations, and he has presented at numerous international conferences. The main theme of his research involves the proteins in milk and the natural enzymes (including plasmin) that degrade them (as well as the exogenous enzymes we often add to change their properties). The significance of milk proteins and enzymes starts in the udder, when physiological processes shape the quality of future dairy products by determining the level and properties of intact casein, and much of Kelly's work has addressed milk quality at this level. He has studied how subsequent processing operations, both conventional (e.g., heating, cheese-making) and novel (e.g., high-pressure processing or homogenization) treatments, affect enzymes, proteins, and their interactions and how the sum of the initial state of the raw material plus the changes induced by processing together influence the characteristics of dairy products. He recently spearheaded the first International Symposium on Indigenous Enzymes in milk.

Kelly has been an editor of the International Dairy Journal since 2005 and sits on the editorial boards of Trends in Food Science and Technology and Innovative Food Science and Emerging Technologies. He is a reviewer for most leading international dairy and food science journals and several international funding authorities. 


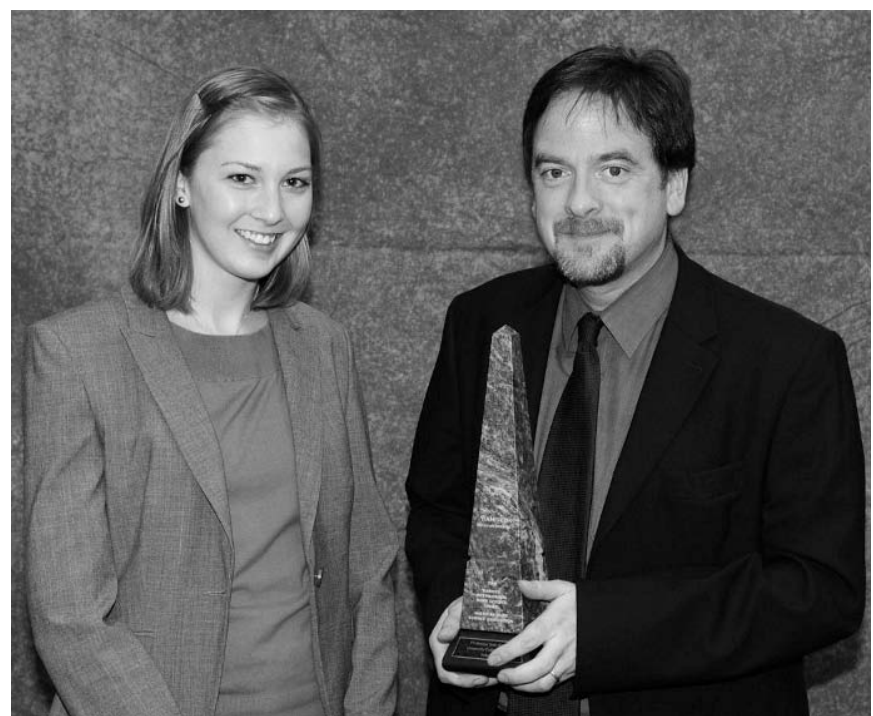

Alan Kelly (right) receives the 2009 Danisco International Dairy Science Award from Alyssa Francl, donor representative (left).

Kelly has a particular interest in graduate education in both dairy and food science, and is currently dean of graduate studies of his university, with responsibility for institutional graduate education strategy. Kelly has been the recipient of two teaching awards: the President's Award for Excellence in Teaching and the Award for Research in Innovative Forms of Teaching and Learning at University College Cork. Kelly is currently director of training of a Food Graduate Development Programme, funded by the Irish Department of Agriculture and Food, which is intended to provide $\mathrm{PhD}$ and MS graduates, through a series of short courses and workshops, with a range of generic, transferable, and disciplinary skills to help them make a maximum positive impact in the global food industry during their careers.

The 2009 Danisco International Dairy Science Award is awarded to Alan Kelly in recognition of his outstanding accomplishments in dairy science and his internationally recognized expertise in the area of emerging processing technologies.

\section{Citation for Jeffrey Reneau Recipient of the 2009 DeLaval Dairy Extension Award}

Jeff Reneau is professor of dairy management at the University of Minnesota. Reneau grew up in New Hampshire and attended the University of New Hampshire, graduating in 1965 with a BS in dairy science. He began graduate school at the University of Minnesota in June 1965. Interrupted by a tour of duty in the US Army, Reneau returned to graduate school at the University of Minnesota, completing an MS in dairy nutrition, and he then went on to receive a DVM at the University of Minnesota. After four years of dairy prac-

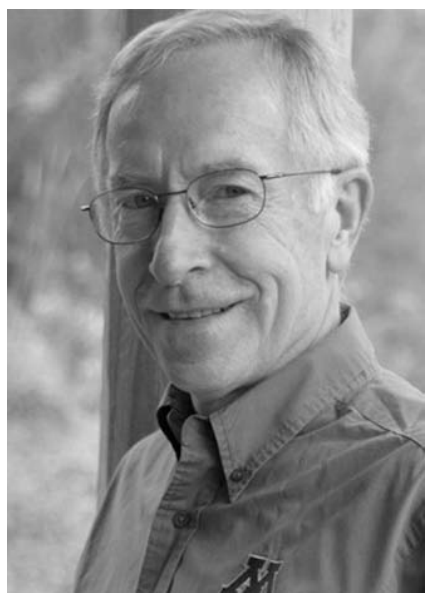
tice in rural Minnesota, Reneau returned to the University of Minnesota in December 1979 as an extension dairy specialist. At the time, Reneau was a pioneer because very few veterinarians were faculty members in departments of animal science. He bridged this gap and was a leader in integrating our knowledge on health, husbandry, and management and how they were connected to many of the problems challenging dairy producers. This approach to evaluating dairy farm operations as a system and trying to define and differentiate causes and effects of dairy problems on whole, not single, entities is still a major emphasis in his extension educational programs today.

With Reneau's leadership, Minnesota was the first state to develop Dairy Diagnostic Teams. Although a major emphasis on the team visit to the farm was milking management and producing quality milk, Reneau was instrumental in developing diagnostic worksheets and tools for teams to use on farms to evaluate milk quality, cow health, dairy farm records, business management, and other components of the farm.

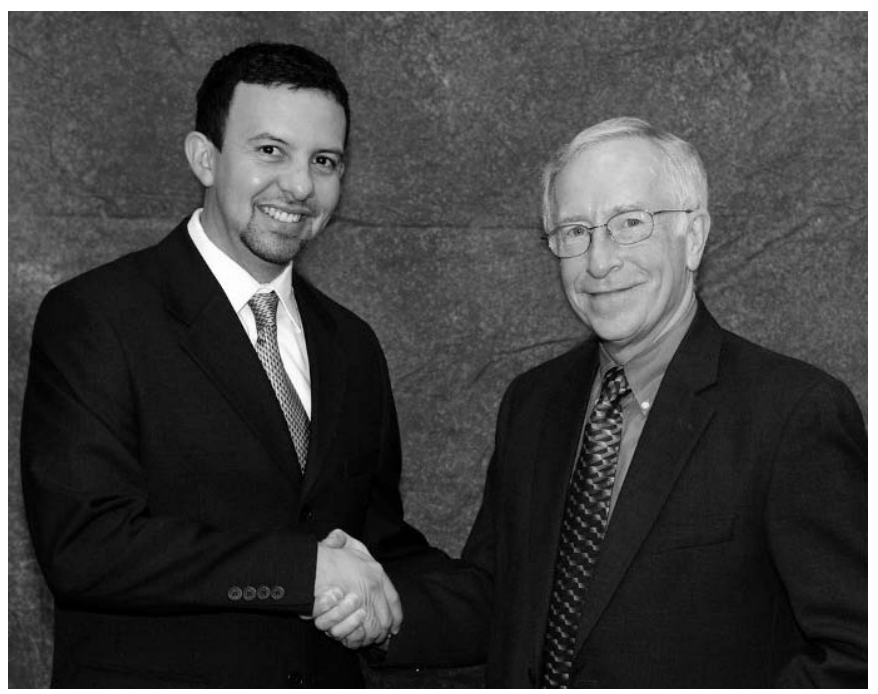

Jeffrey Reneau (right) receives the 2009 DeLaval Dairy Extension Award from Mario Lopez-Benavides, donor representative (left). 
In 2003, Minnesota's somatic cell count (SCC) levels were climbing and milk quality was deteriorating. Through Reneau's efforts, a team of concerned experts representing several sectors of the dairy industry was formed to develop a major educational effort to reduce SCC in Minnesota dairy herds. This led to a united dairy industry effort called Quality Count\$, a statewide cooperative campaign to improve milk quality in Minnesota. As part of the Quality Count $\$$ program, it was important to develop a way for dairy herds and the industry to measure true changes in SCC. Reneau and his graduate student had begun to implement statistical process control methodology for on-farm performance monitoring. Today this effort has become an automated Internet-based commercial entity called MilkLab through which participating milk plants are able to provide immediate alerts to their field personnel and dairy farmer patrons on changing SCC levels and milk components.

Most recently, Reneau and his industry colleagues expanded beyond SCC diagnostic capabilities and moved into real-time, on-farm scoring and statistical process control diagnostic analysis. In an effort to alleviate the problem of cumbersome and time-consuming data collection, Reneau and colleagues have begun using smart phones and hand-held computers to capture and transmit data collected on the farm to an Internet server for real-time analysis and report generation.

Reneau has been an active member and participant in ADSA for over 30 years. He has served on many national and regional ADSA program committees. He also is a member of the National Mastitis Council and served in several leadership roles, including the presidency of that organization.

\section{Citation for David Winston Recipient of the 2009 Hoard's Dairyman Youth Development Award}

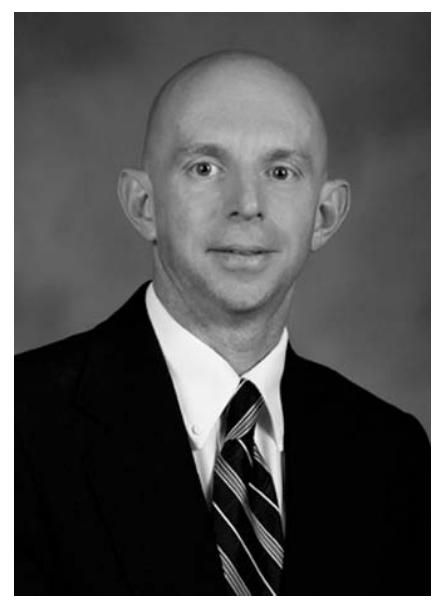

David Winston is the winner of the 2009 Hoard's Dairyman Youth Development Award. After serving as a county and district extension agent, Winston was named extension dairy scientist for $4-\mathrm{H}$ youth at Virginia Tech in 1994.

Winston is highly regarded for his work with young people in his state and nationally. $\mathrm{He}$ has developed a well-balanced program that integrates

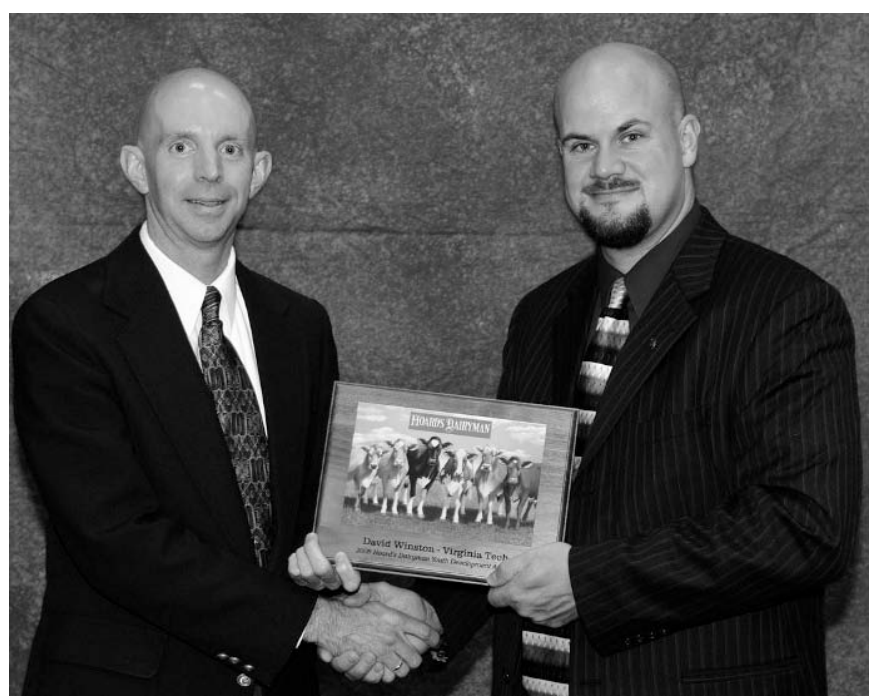

David Winston (left) receives the 2009 Hoard's Dairyman Youth Development Award from Corey Geiger, donor representative (right).

training sessions, competitions, and curriculum support. Winston has coached four national $4-\mathrm{H}$ quiz bowl teams over the past six years at the North American Livestock Exposition. His dairy quiz bowl study guide is used by youth across the United States to prepare for competitions. It is a comprehensive resource that includes material on nutrition, genetics, milk quality, animal health, dairy promotion, and reproduction. Winston oversees a unique activity, the June Dairy Month 4-H Poster Contest, which reaches many youth who are not from traditional dairy backgrounds. Each year, approximately 3,000 youths participate in this dairy promotion contest. In 2003, Winston became a member of the National 4-H Dairy Conference planning committee and currently serves as vice chair. This event includes educational workshops, field trips, and motivational speakers. Each year, approximately 180 youth delegates from across the nation attend this program.

Along with 4-H and FFA youth, Winston has affected the lives of many college students. He has advised the Dairy Club of Virginia Tech since 1997 and currently serves as its permanent advisor. Under his leadership, the club has been named Outstanding Chapter by the ADSA Student Affiliate Division four times. In addition, four students have placed first nationally in the undergraduate presentation contest, and three have been named the Outstanding ADSA-SAD Student under his guidance. Winston was named the Outstanding Student Affiliate Advisor in 2005 after advising the national organization for three years.

In addition to his club advising, Winston teaches two courses in the Department of Dairy Science. He serves as assistant coach of the Virginia Tech dairy challenge 
team and has chaired the Southern Regional Dairy Challenge planning committee.

Winston has been active in many organizations. He serves as president of the Southern Branch of ADSA, is involved with the Dairy Calf and Heifer Association, and is advisor of the Virginia Tech College of Agriculture and Life Sciences Leadership Council. He has been recognized with many awards and honors because of his outstanding work and vision. These include the College of Agriculture and Life Sciences Diversity Enhancement Award, honorary lifetime membership in the Virginia Junior Holstein Association, and the award for Distinguished Young Alumnus from the Virginia Tech Ag Alumni Organization.

In closing, David Winston has developed an outstanding 4- $\mathrm{H}$ dairy program in Virginia and has contributed to youth development across his state and across the nation. Winston is a most worthy recipient of the Hoard's Dairyman Youth Development Award for his leadership, innovative programs, and emphasis on character and integrity.

\section{Citation for Rafael Jiménez-Flores Recipient of the 2009 International Dairy Foods Association Research Award in Dairy Foods Processing}

Rafael Jiménez-Flores has served the dairy industry as a professor of dairy chemistry and technology for nearly 20 years. Jiménez-Flores received his BS in phar-

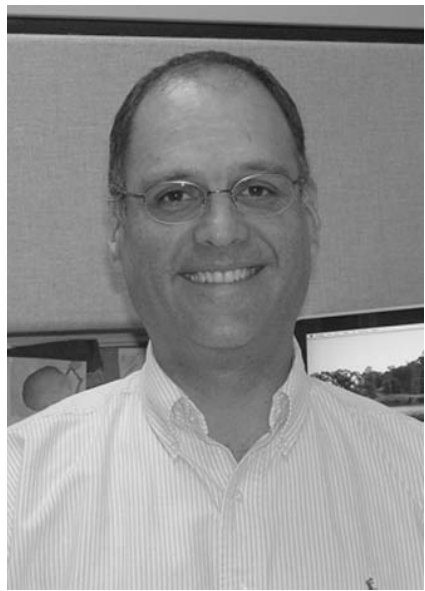
maceutical chemistry and food science from La Salle University in Mexico City, Mexico, in 1981, his MS in food science from Cornell University in 1984, and $\mathrm{PhD}$ in agricultural and environmental chemistry from the University of California at Davis in 1989. He went on to become an assistant professor in the Department of Food Science and Technology at the University of Illinois in 1990, where his research centered on applications of molecular biology to bovine milk proteins. Jiménez-Flores was among the first scientists to clone milk proteins for use in studies of structure and function. Jiménez-Flores joined the faculty of the California Polytechnic State University as an associate professor in 1995, was promoted to professor in 1999, and continues to serve there as a distinguished faculty

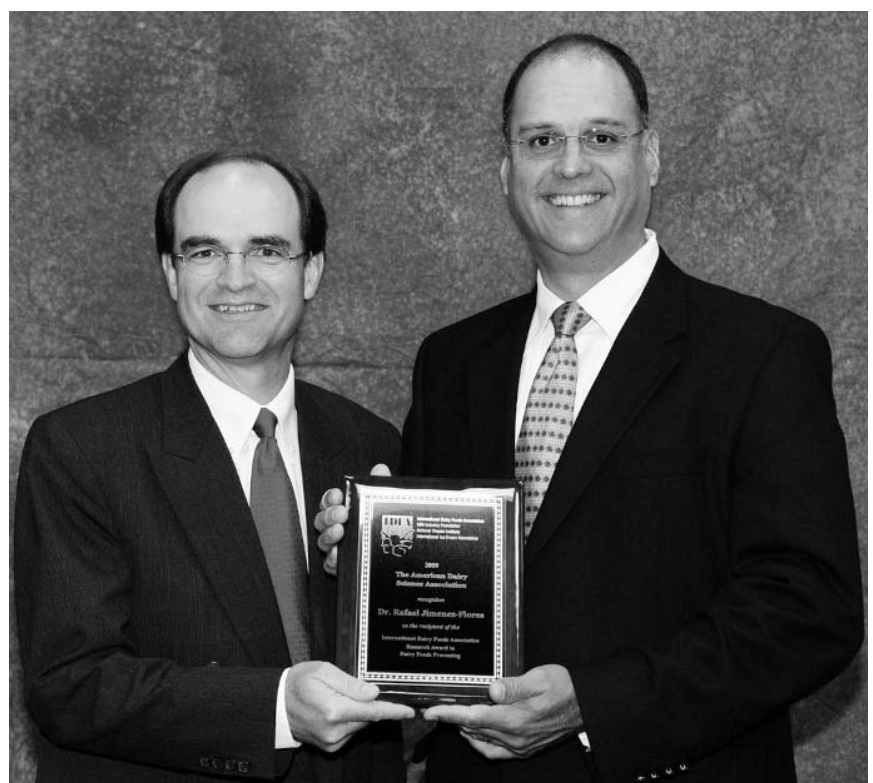

Rafael Jiménez-Flores (right) receives the 2009 International Dairy Foods Association Research Award in Dairy Foods Processing from Eric Bastian, donor representative (left).

member and member of the Dairy Products Technology Center at California Polytechnic.

Over the course of his career, Jiménez-Flores has published nearly 80 peer-reviewed journal articles, coauthored 10 book chapters, and been awarded 3 patents. His research program has been particularly productive during the past five years, resulting in the publication of 48 refereed papers. Much of this work has focused on innovative separation and processing technologies for recovering highly functional and valuable phospholipids from buttermilk. Buttermilk, the undervalued by-product of butter manufacture, is rich in milkfat globule membrane material, which in turn is rich in phospholipids that may have nutritional benefits to humans by providing antioxidative, anticarcinogenic, and antiatherogenic properties. Jiménez-Flores and colleagues have researched innovative approaches to isolate, concentrate, and characterize functional milkfat globule membrane components using microfiltration and supercritical fluid extraction technologies. This work has opened the door to new functional ingredients for use in novel dairy beverages. Currently, JiménezFlores is an advisor for seven graduate students and two postdoctoral fellows. He has served as chair of the ADSA Milk Protein and Enzyme Committee and chair of the Journal of Dairy Science Journal Management Committee. He is currently a section editor of the Journal of Dairy Science Dairy Foods section. He is the 2003 recipient of the prestigious ADSA Kraft-Milk Industry Foundation Outstanding Teaching Award in Dairy Manufacturing. 


\section{Citation for Rex Powell Recipient of the 2009 International Dairy Production Award}

Rex Powell received his BS and MS degrees from Michigan State University in 1964 and 1968, respectively, followed by his $\mathrm{PhD}$ in animal breeding from

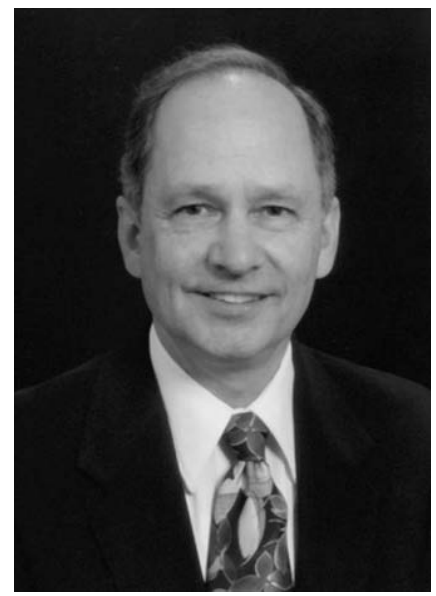

Iowa State University in 1972. His first employment was as a graduate research assistant at Michigan and Iowa State Universities, but it was during his 33year career as a research geneticist at the Animal Improvement Programs Laboratory (USDA-ARS) in Beltsville, Maryland, that he made his mark as an internationally renowned scientist.

Powell has been an international leader in cooperative research and efforts to coordinate genetic evaluation of dairy cattle to enhance genetic progress on a global basis. Advances in national evaluations, coupled with the opportunity provided by frozen semen for easy transport of genetic material, led to a need to compare (translate) estimates of genetic merit across countries. Comparison methods evolved from conversion equations between pairs of countries to today's

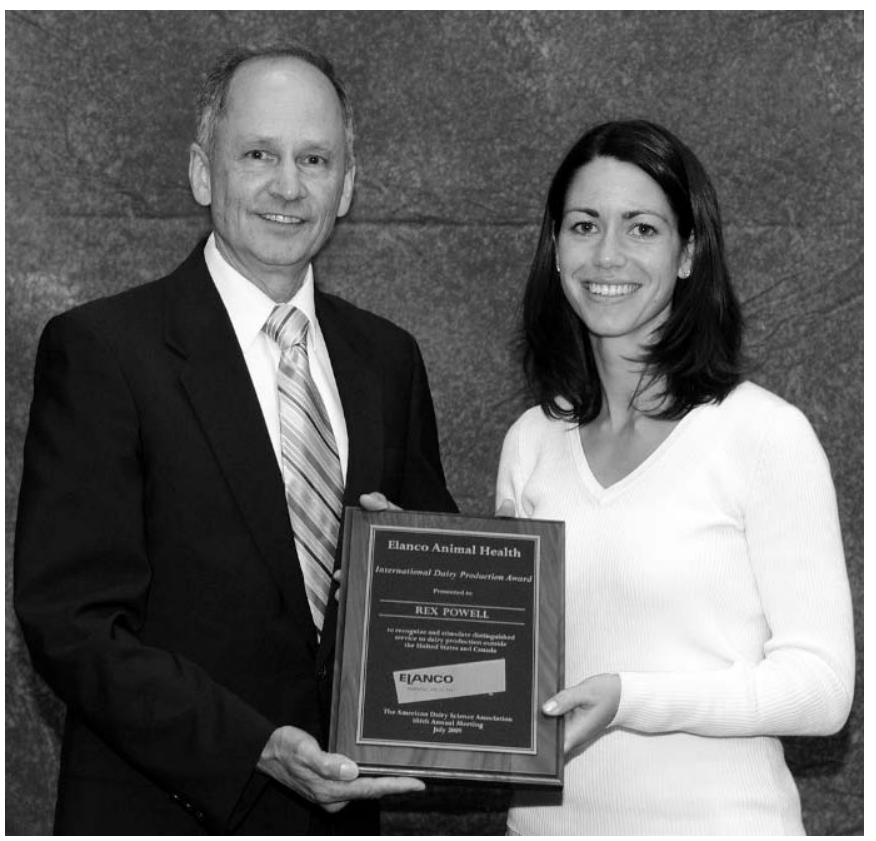

Rex Powell (left) receives the 2009 International Dairy Production Award from Kelly Smith, donor representative (right). international effort with simultaneous comparison of 25 Holstein populations as well as international evaluations for 5 other breeds for a total of nearly 300 breed population-trait sets of evaluations. Powell has been deeply committed to this effort since the late 1970s. His research on international comparison of genetic evaluations of dairy bulls is without precedent. He has published over 300 scientific and popular articles, 206 as senior author. Of these, 111 were directly related to international dairy production. He was the US representative to the International Bull Evaluation Service (Interbull) from its inception in 1983 and served on its steering committee for 20 years. In 2003, Rex Powell was the local organizer for the first US-hosted Interbull Technical Workshop. His invited review (coauthored by H. D. Norman) in the 2006 ADSA Centennial Issue titled "Major Advances in Genetic Evaluation Techniques" is an excellent summary of the progress that has been made in the dairy cattle arena over 25 years.

Powell's contributions to the dairy industry worldwide have been recognized through numerous awards. ADSA awards alone include the J. L. Lush Award in Animal Breeding (1997) and the Northeast ADSA-ASAS Distinguished Service Award (2006). In 2005, Powell became an ADSA Fellow. He also received the National Association of Animal Breeders Research Award (1994) and the National Dairy Herd Information Association (NHIA) Outstanding Service Award (2005). Furthermore, his group received the National DHIA Award of Special Appreciation in 1991 and the USDA Distinguished Service Unit Award in 1991. During his career, Powell received invitations to make presentations related to the dairy industries in 26 countries.

Rex Powell's service to the dairy industry is reflected in the numerous scientific and industry committees on which he has served. He has been a member of ADSA for the past 42 years and has served on the editorial board of the Journal of Dairy Science. Currently retired, Powell is still very active and serves as a volunteer at the Animal Improvement Programs Laboratory in Beltsville. He recently presented a poster at the 2009 joint annual meeting. Rex Lynn Powell is a worthy recipient of the 2009 International Dairy Production Award.

\section{Citation for Thomas Lawlor Jr. Recipient of the 2009 J. L. Lush Award in Animal Breeding}

The recipient of the 2009 J. L. Lush Award in Animal Breeding is Thomas J. Lawlor Jr., director of research for the Holstein Association USA (Brattleboro, Vermont). His research efforts led to improvements in breeding tools that are used by dairy farmers on a daily 
basis; for example, development of an inbreeding calculator, whereby the potential economic impact from inbreeding depression on a proposed mating is provided.

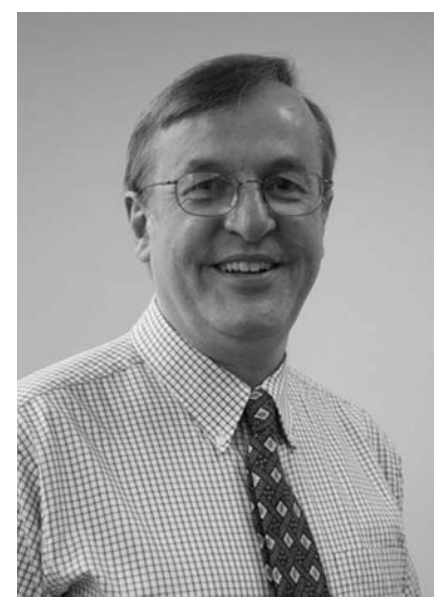

Lawlor has worked on the development of a total performance index that can be used to improve the profitability, fertility, health, and well-being of cows. His research on conformation traits has led to the development of the current udder and feet-and-legs composites for US Holsteins. Those two composites are consistently among the top five traits used by commercial Holstein breeders around the world.

Lawlor received his BS in animal science with honors and distinction from the University of Massachusetts, his MS in animal breeding and genetics from Montana State University, and his $\mathrm{PhD}$ in animal breeding and genetics from Cornell University. After serving as a postdoctoral research geneticist at the Animal Improvement Programs Laboratory, ARS, USDA (Beltsville, Maryland) and an assistant professor at the University of Connecticut, he joined Holstein Association USA in 1986 as a senior research scientist and became director of research in 1990.

Lawlor was at the forefront of the implementation of the first multitrait animal model for routine national genetic evaluations, and he was among the first to promote the more accurate predictions of breeding values by combining local domestic evaluations for conformation traits into international genetic evaluations. He currently serves as the project leader for the North American Consortium, which performs supporting research for the Interbull Centre (Uppsala, Sweden) and calculates routine international genetic evaluations of 21 conformation traits for five major dairy breeds.

His long-term interest in improving the longevity of Holstein cows was instrumental in the enhancement of direct genetic estimates for productive life by including the effect of correlated traits. Later, he helped to show that the longer lactation lengths of modern-day cows require a change in the definition of productive life. Recently, his research has looked at improving cow fertility and the practical applications of cloning and genomics. Lawlor has been an integral part of the US Council on Dairy Cattle Breeding, having held every council position from voting member to chairman.

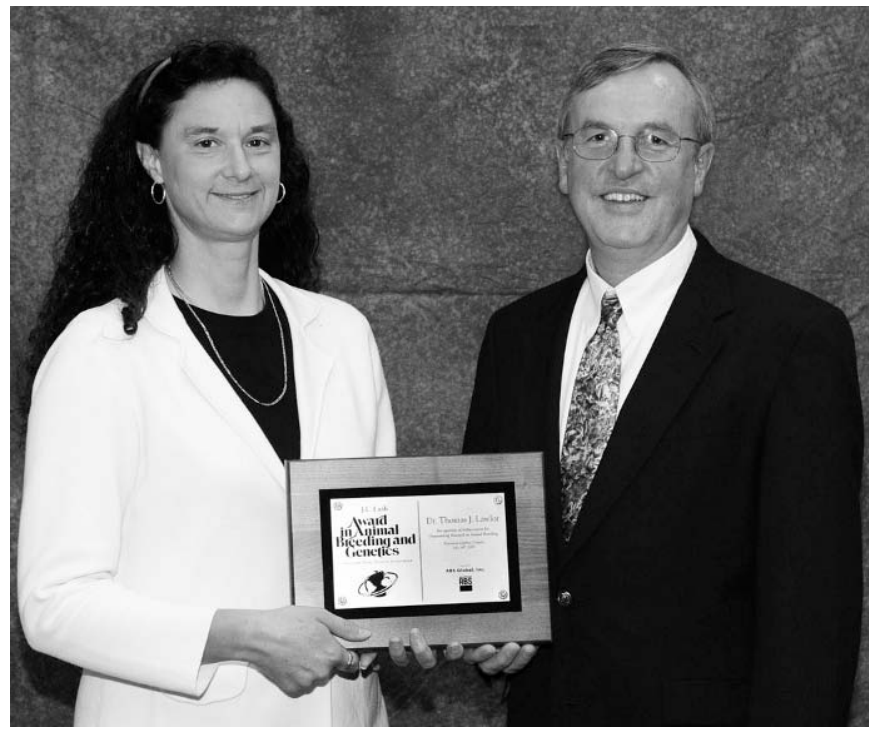

Thomas Lawlor Jr. (right) receives the 2009 J. L. Lush Award in Animal Breeding from Marjorie Faust, donor representative (left).

One of Lawlor's beliefs is that a research project is not complete until the results reach the ultimate end user, the farmer. He is as comfortable speaking with a farmer about the desirable traits of their cows as he is talking to an international group of scientists about the latest change in genetic evaluations. His ability to talk about complex genetic principles and explain them in an easy-to-understand way has led others to adopt and expand the use of genetic information. He is a frequent speaker at regional, national, and international scientific and industry meetings and conferences. Lawlor is the first industry scientist to win this prestigious research award.

\section{Citation for Young Park Recipient of the 2009 Land O' Lakes Inc. Award Citation}

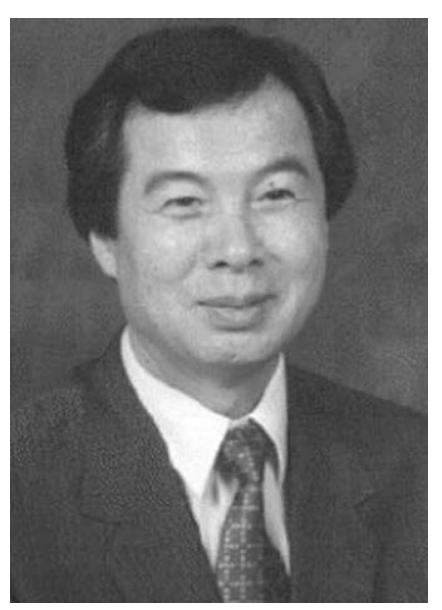

Young W. Park is a professor at the Georgia Small Ruminant Research and Extension Center, Fort Valley State University (FVSU), Fort Valley, Georgia, and adjunct professor in the Department of Food Science and Technology, University of Georgia, Athens. Park has distinguished himself in dairy production and dairy foods development, especially in goat milk 
and dairy goat products research, for the past 29 years. Based on his excellence in dairy goat and small ruminant milk research, Park was nominated to the 2000 outstanding scientists of the 21st century three times by the International Biographic Centre, Cambridge, England. In addition, two of his recent publications on goat and sheep milk were the first and third most downloaded research papers in the world in veterinary science and small ruminant dairy products.

Park's contribution to the processing; extended shelflife; and chemical, rheological, microbiological, and sensory aspects of dairy foods has been notable in the area of small ruminant dairy production. His research has shown that extended frozen storage for goat milk cheeses can be successfully accomplished and marketed with acceptable quality, which is important in overcoming the seasonality of goat and sheep milk production. With over $\$ 2$ million in competitive and Evan-Allen grant funds, Park has developed an internationally recognized goat milk product research program. He had previously established a similar dairy goat research program at the International Dairy Goat Research Center at Prairie A\&M University (Texas A\&M University System).

Park came to the United States in 1974 after receiving his BS in Korea. He earned his MS at the University of Minnesota and $\mathrm{PhD}$ at Utah State University. He also earned his M. Div. and D. Min. at the Northern Baptist Theological Seminary. Park has published more than 240 publications including 3 books; 27 book chapters; and refereed journal articles, abstracts, and invited

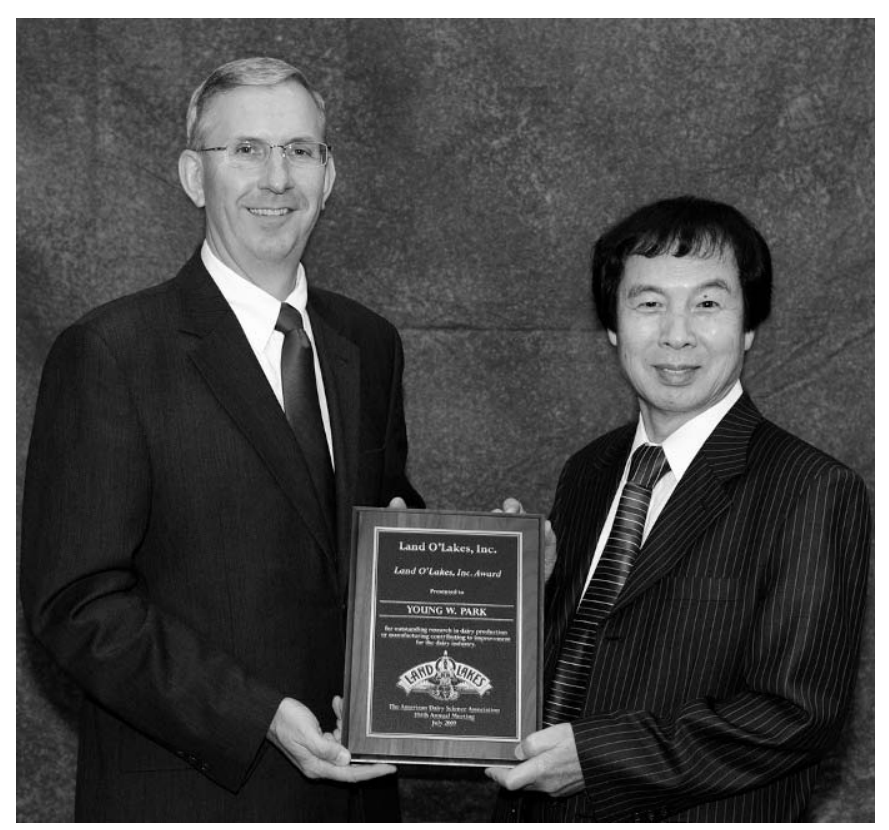

Young Park (right) receives the 2009 Land O'Lakes Award from Tom Gruetzmacher, donor representative (left). symposia papers. Because of his scholarly activities in international dairy production, he has been invited to numerous international conferences, seminars, and symposia in numerous countries including Finland, Brazil, India, China, New Zealand, Australia, France, Spain, Italy, Korea, Mexico, Canada, Argentina, and the United States.

Park has taught 10 dairy production and food chemistry/processing related courses and has served as an editorial board member for Small Ruminant Research for the last 19 years. He has also served as a local church pastor for the past 20 years. Park has been one of the leading advocators for production and utilization of minor domestic and wild dairy species, other than dairy cows. One of his greatest achievements is the publication of three recent books as editor, or coeditor, which has drawn global attention to dairy production and bioactive compounds in milk and dairy products. The titles of the books are Handbook of Milk of NonBovine Mammals, Goat and Sheep Milk, and Bioactive Components in Milk and Dairy Products.

\section{Citation for Dale Olver Recipient of the 2009 Land O'Lakes, Purina Feed LLC Teaching Award in Dairy Reproduction}

Dale Olver of Pennsylvania State University is the recipient of the 2009 Land O'Lakes, Purina Feed LLC Teaching Award in Dairy Production. He is an instructor in the Department of

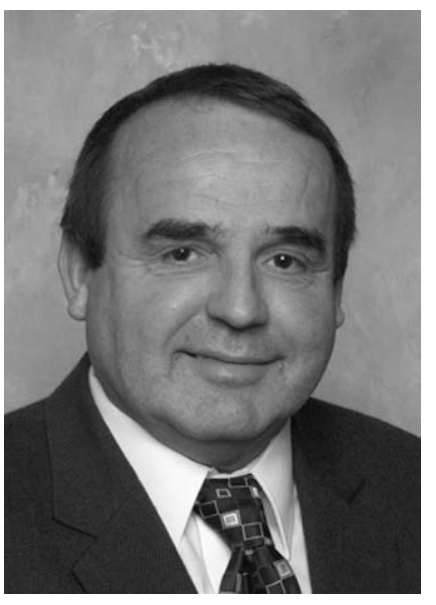
Dairy and Animal Science and joined the faculty in 1989. He is known for his enthusiastic approach and commitment to students. Olver is the primary instructor or a major coinstructor in nine animal science and general courses in the College of Agricultural Sciences. He strives to integrate scientific principles with industry trends and examples to create an active learning environment. His courses

are known for their current information and relevance, and he consistently receives very high evaluation scores from students and peers.

Olver has been the teacher of Animal Science 001 in both the fall and the spring semesters for the past 12 years. This four-credit course typically has an enrollment of 100 to 120 students each semester. Although 


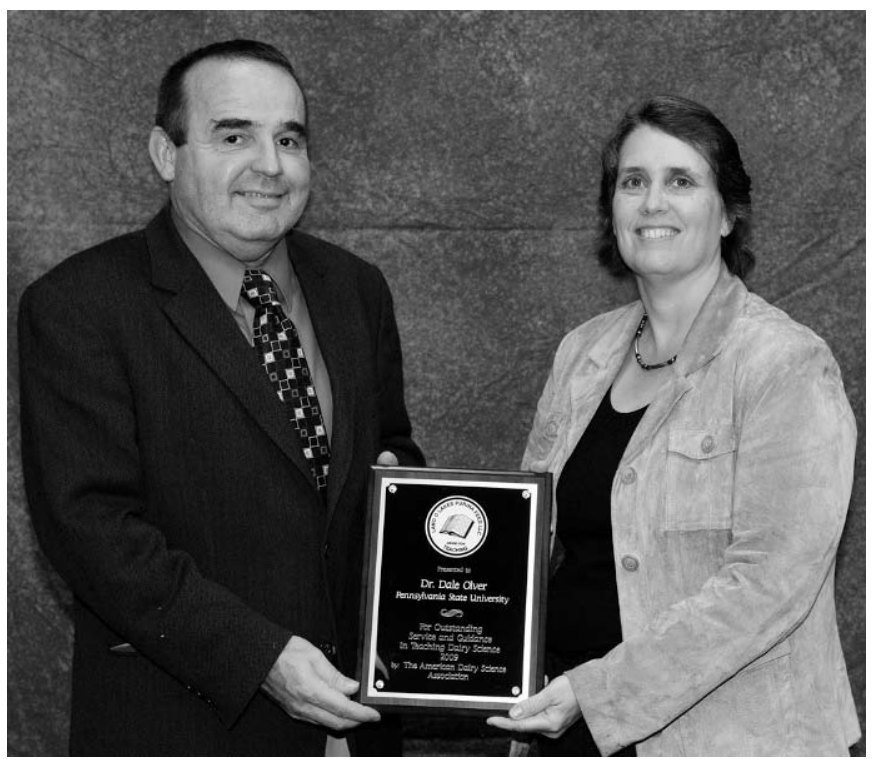

Dale Olver (left) receives the 2009 Land O'Lakes Purina Feed LLC Teaching Award in Dairy Production from Cindie Luhman, donor representative (right).

about $60 \%$ are majoring in animal sciences, students from a variety of majors typically enroll. The course consists of three lectures and four lab sections per week and has earned a reputation for being demanding but fair. Despite 8:00 a.m. lectures, students consistently rate this course very highly in the Student Rating for Teacher Effectiveness. Olver teaches or coteaches several other dairy-related courses. One of these, Dairy Cattle Evaluation and Selection, relies heavily on integration of information in a practical way so future dairy industry leaders can make informed decisions. He also contributes to Penn State's junior-level dairy management course, and he and Gabriella Varga founded a course called Dairy Problem Solving to add additional benchmarking and decision-making skills to the curriculum. Olver has a strong commitment in mentoring and retaining first-year students. Since 1990, he has been co-instructor of Ag 150S, Be a Master Student! In addition, he and several colleagues created Introduction to Penn State Dairy Science to introduce incoming freshmen and transfer students to the dairy faculty, research and extension programs, the Pennsylvania dairy industry, and current dairy issues.

In addition to his course work, Olver has coached the Penn State Dairy Cattle Judging Team since 1989. He has helped develop 30 All-American intercollegiate judges, including the high individual at the National Intercollegiate Contest in both 2007 and 2008. Olver has served as co-advisor of the Penn State Dairy Science Club since 1989. The club has been honored by ADSA as Outstanding Chapter 11 years, runner-up 7 years, and third once during his 19-year tenure. He has helped develop numerous national officers and undergraduate presentation winners.

Olver has received other recognitions throughout his career. Penn State's College of Ag Sciences Alumni Society honored him with their Excellence in Academic Advising Award in 2003, and he received Penn State's Gamma Sigma Delta Teaching Award in 2004. He was recognized as the ADSA-SAD Outstanding Advisor in 1994 and received the Hoard's Dairyman Youth Development Award in 2006.

\section{Citation for Lisbeth Goddik \\ Recipient of the 2009 Milk Industry Foundation Teaching Award in Dairy Manufacturing}

Lisbeth Goddik, associate professor in the Department of Food Science and Technology at Oregon State

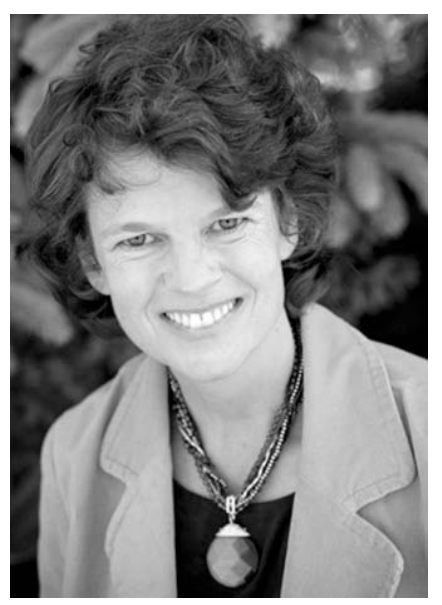
University (OSU), is the recipient of the 2009 Milk Industry Foundation Teaching Award in Dairy Manufacturing. She is also the OSU dairy processing extension specialist. She received her MS from Cornell University under the supervision of Dave Barbano and her $\mathrm{PhD}$ from Oregon State University. Her work experience includes three years at Yoplait's international research center in Paris and internships as production worker at three Danish dairy companies. She recently completed a one-year sabbatical in France studying raw milk cheese production.

Goddik teaches dairy processing, dairy processing lab, and cheese making. She is consistently ranked by students as one of the top teachers in the OSU College of Agriculture. Over the past two years, she has completely changed her teaching philosophy. She no longer gives lectures. Instead, students are responsible for studying the material prior to class and can ask questions within class. Her classroom contact time is utilized for discussions, group projects, and analyzing case studies from her extension work. Students take turns giving 5- to 10-minute presentations covering select homework assignments. All these activities are meant to foster critical thinking and help students understand the application of dairy science.

Thirty years ago, OSU closed its dairy pilot plant. Goddik has overseen the remodeling and construction 


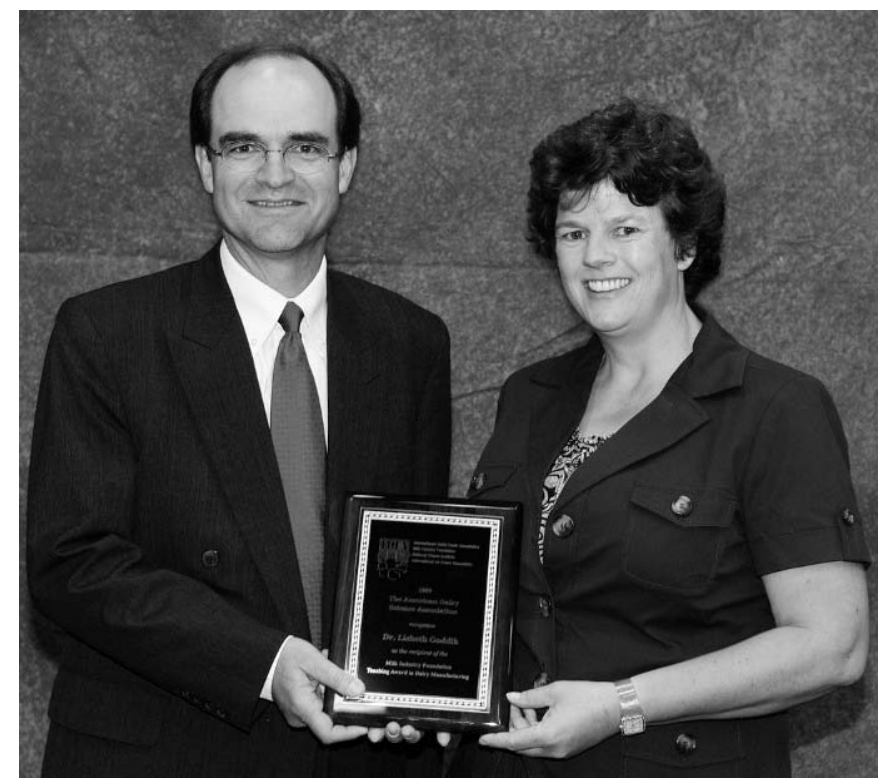

Lisbeth Goddik (right) receives the 2009 Milk Industry Foundation Teaching Award in Dairy Science from Eric Bastian, donor representative (left).

of a new specialty cheese pilot plant. State-of-the-art cheese-making equipment was obtained from France and Holland. Funding was obtained from grants, donations, golf tournaments, and cheese auctions. The new pilot plant is also equipped to become a training facility for Good Manufacturing Practices, Sanitation Standard Operating Procedures, and so on. The facility is not only used for dairy processing classes but also by the student club that has enthusiastically embraced the new opportunity for making cheese. This enthusiasm is reflected in the renewed interest of OSU students in pursuing dairy-related careers. For example, in this past year, six graduates started working with dairy processing companies in Oregon and Washington.

Goddik has also offered numerous short courses to employees within Oregon and Washington's dairy processing industry. Some courses are taught on campus, and others are taught in processing plants. She has developed a cheese-on-wheels program where she loads four cheese vats into a cargo van and travels to distant locations in Oregon to provide hands-on training to Oregon's artisan cheese makers.

Within her research program, she has supervised four $\mathrm{PhD}$ students and six MS students. Her research has focused on topics of interest to Oregon's dairy industry such as whey quality, cheese technology, protein stability, and potential pathogens. Currently she is collaborating with an agricultural economist to develop economic data for startup and operating costs for artisan cheese makers.

\section{Citation for Malek Abdelqader Recipient of the 2009 National Milk Producers Federation Richard M. Hoyt Award}

Malek Abdelqader received a BS degree in veterinary medicine from Jordan University of Science and Technology. After graduation, he worked for two years as a

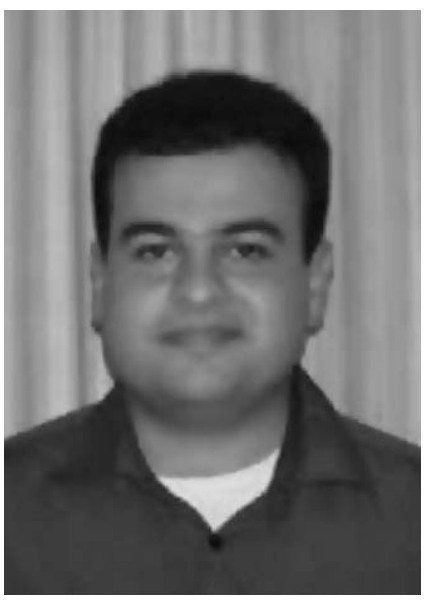
veterinarian and manager of a poultry farm. Abdelqader also received an MSc degree in animal science with an emphasis on ruminant nutrition from McGill University, Montreal, under the supervision of Arif Mustafa and a $\mathrm{PhD}$ degree in animal science with an emphasis on dairy science and ruminant nutrition under the supervision of Arnold Hippen.

Abdelqader's doctoral research evaluated the potential of corn germ as an alternative fat source and its feeding value compared with distillers grains in dairy cow diets. Corn germ has a high net energy of lactation value, contains some fermentable starch, and has lower concentrations of ruminally undegradable protein than distillers grains. His research concluded that corn germ is a suitable alternative source of fat for increasing energy in lactating dairy cow diets when included at up to $14 \%$ of dietary DM.

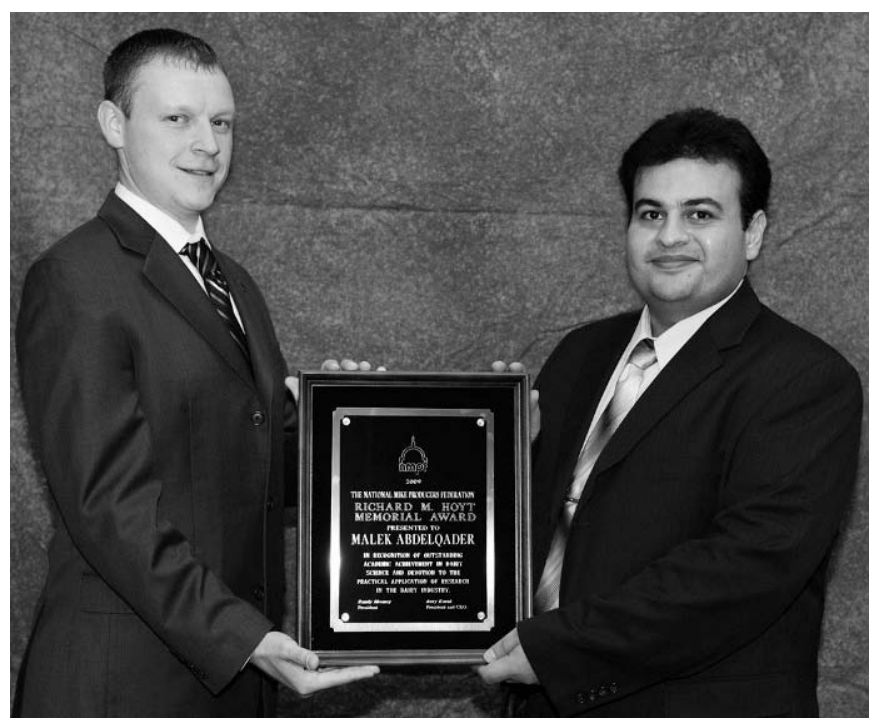

Malek Abdelqader (right) receives the 2009 National Milk Producers Federation Richard M. Hoyt Award from Jamie Jonker, donor representative (left). 
The results from this project led him to write a grant proposal to further explore the value of feeding corn germ compared with distillers grains in dairy cow diets. This grant was funded by the South Dakota Corn Utilization Council. This study suggested that fatty acids in corn germ are relatively protected and slowly released into the rumen compared with fatty acids in distillers grains. Further indications are that distillers grains, when compared with corn germ that has not gone through fermentative processes for ethanol production, may contain greater concentrations of free oil (fatty acids not associated with cellular contents or particulate matter) that may be more available during ruminal digestion, thus creating a greater quantity of biohydrogenation intermediates and consequently causing milk fat depression.

Abdeqader's findings present valuable information to dairy nutritionists and industry professionals, providing them with research-based recommendations for inclusion rates and diet formulation with these by-products. His findings also show that these inexpensive by-products can improve the profitability of dairy producers and increase flexibility during diet formulation.

Currently, Abdelqader works as a postdoctoral research associate at South Dakota State University. His current research is focused on the utilization of corn byproducts as an alternative source of nonforage fiber in dairy cow diets through the study of microbial protein synthesis, ruminal nutrient digestion, flow of nutrients out of the rumen to the small intestine, and nutrient excretion of dairy cows.

Abdelqader has published one peer-reviewed article and five conference abstracts. At the 2007 Midwest ADSA meeting, Abdelqader was selected as an Invited Young Scholar.

\section{Citation for William P. Weiss \\ Recipient of the 2009 Nutrition Professionals Inc. Applied Dairy Nutrition Award}

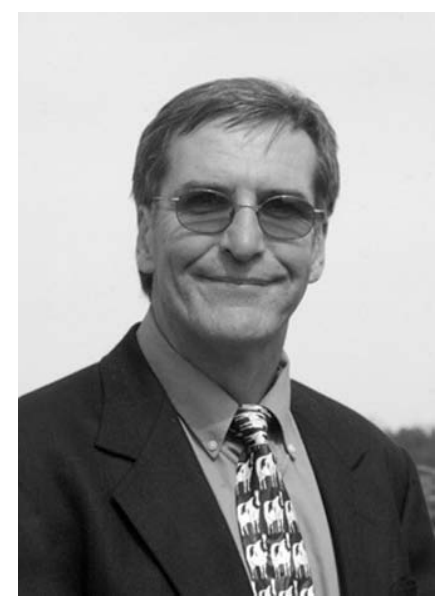

William P. Weiss is this year's recipient of the $\mathrm{Nu}$ trition Professionals Inc. Applied Dairy Nutrition Award. Weiss received BS and MS degrees from Purdue University in 1980 and 1981, respectively. He completed his $\mathrm{PhD}$ in dairy nutrition with H. R. Conrad in 1985 at the Ohio Agricultural Research and Development Center (OARDC) of The

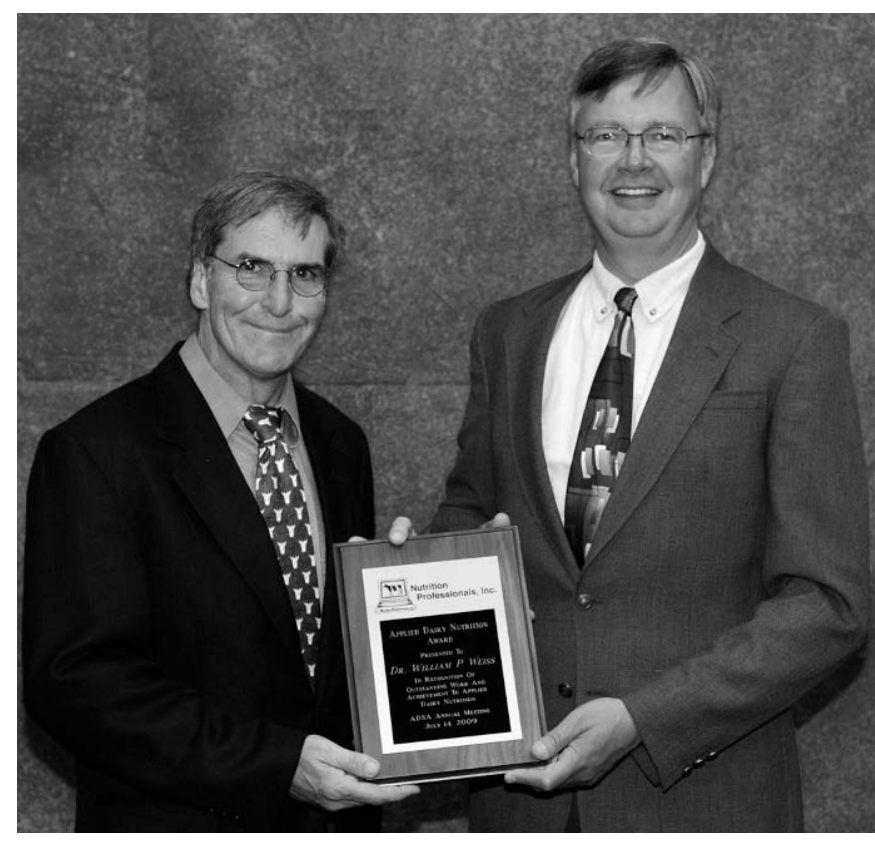

William P. Weiss (left) receives the 2009 Nutrition Professionals Inc. Applied Dairy Nutrition Award from Steve Woodford, donor representative (right).

Ohio State University. Initially after graduate school he was an assistant professor at North Dakota State University before returning to the OARDC in 1988 and becoming full professor in 1998 .

Weiss is recognized for the breadth and depth of his research and knowledge in dairy cattle nutrition. His primary research project areas have been in forage utilization, estimation of feed energy, and mineral and vitamin nutrition and animal health. Of his 91 peerreviewed journal publications, many initially delved into effects of agronomic, harvesting, and storage practices on the feeding value of forages across a spectrum of grass, legume, and corn silages. Evaluations of these forages were done using various laboratory techniques, in vitro methods, and ultimately cow production and digestion trials. He has extensively evaluated the beneficial effects of vitamin $\mathrm{E}$ during both prepartum and postpartum periods on cow immune status and overall milk production. This has resulted in the widespread application of feeding greater levels of vitamin $\mathrm{E}$ to dairy cows to capture these benefits. He has quantitated interactions and appropriate dietary levels of selenium with vitamin $\mathrm{E}$ to maximize benefits of both, as well as evaluated the role of vitamin C. Weiss established dietary levels and benefits of biotin on cow foot health and milk production. Earlier studies of copper were followed by extensive reviews of mineral digestion and metabolism and specific studies establishing more definitive requirements for magnesium and best use of major dietary magnesium sources. Perhaps his greatest 
research contributions and implementations have been in estimation of feed energy. Weiss has utilized the gamut of his research data from forages, fats, diets, and various feedstuffs, along with extensive literature and data reviews, to develop a more quantitative and workable methodology to estimate more appropriate dietary energy values for dairy cows. This prodigious effort was incorporated into the 2001 National Research Council Nutrient Requirements of Dairy Cattle, of which Weiss was a key contributor.

Weiss has applied his research and dairy cattle nutrition knowledge on many fronts. He assisted in the development of new courses in applied dairy cattle nutrition and digestive physiology, teaches sections on nutrition in various other courses, and teaches various continuing education courses in dairy nutrition management and problem solving. Weiss has given 143 invited presentations in the United States in various venues and has provided 50 lectures or courses in 16 other countries.

Weiss has also lent his services to ADSA by being a reviewer, section editor, and centennial section editor for the Journal of Dairy Science. He has been sought out by various entities for his quantitative, objective, and critical abilities to write and speak clearly in communicating knowledge for use in dairy cattle nutrition, and he often does this with a wry sense of self-deprecating humor.

\section{Citation for Jose Eduardo P. Santos Recipient of the 2009 Pfizer Animal Health Physiology Award}

The recipient of the 2009 Pfizer Animal Health Physiology Award is Jose Eduardo P. Santos, associate professor in the Department of Animal Sciences at

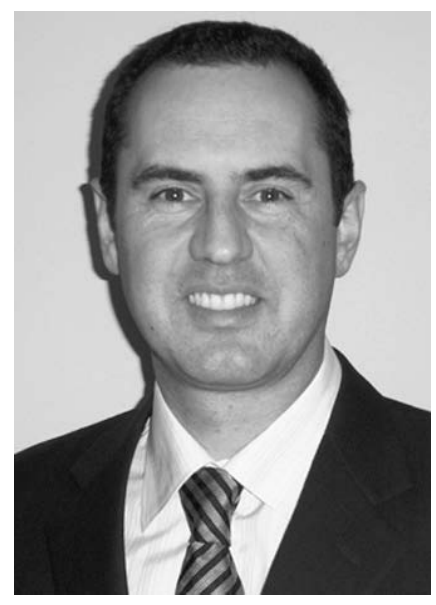
the University of Florida. He grew up in Brazil and obtained his DVM degree from São Paulo State University in Botucatu, Brazil, in 1992. He received his $\mathrm{MS}$ and $\mathrm{PhD}$ degrees in ruminant nutrition from the Department of Animal Sciences at the University of Arizona in 1995 and 1997, respectively. After his graduate program, he completed a clinical residency in dairy production medicine in the School of Veterinary Medicine at the University of California at Davis in 2000. He spent eight years on the faculty of the School of Veterinary Medicine at the University of Cali-

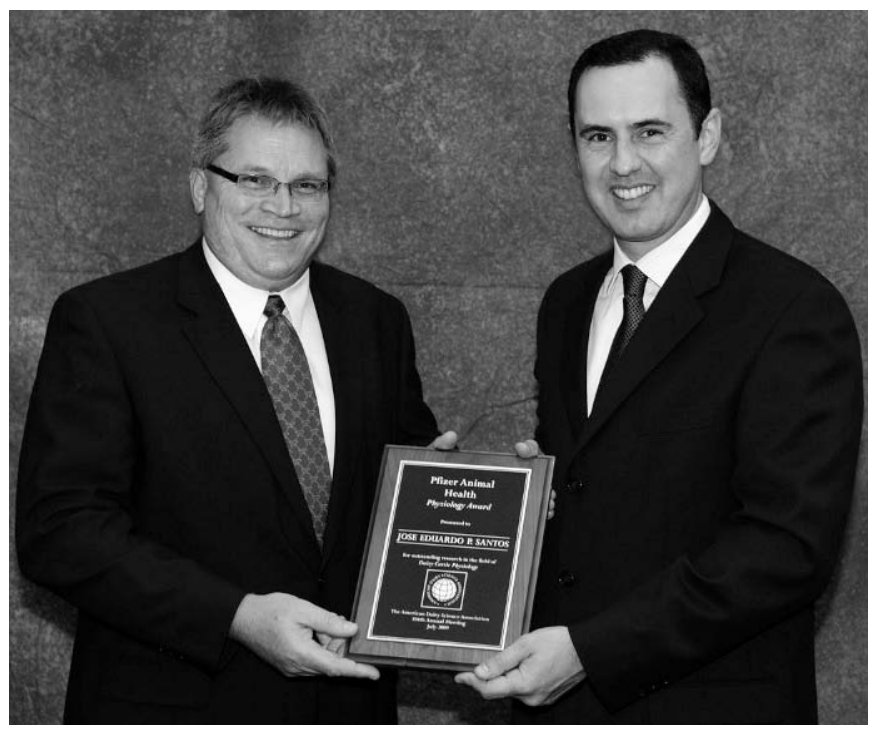

Jose Eduardo P. Santos (right) receives the 2009 Pfizer Animal Health Physiology Award from Todd Meinert, donor representative (left).

fornia at Davis and, in 2008, moved to the University of Florida. He is noted for his applied and basic research on reproductive physiology and nutritional management to enhance reproduction, health, and lactation performance of dairy cattle. His extension activities at the University of Florida focus on dairy cattle nutrition and reproduction.

Santos has been a pioneer in implementing and testing research hypotheses with a large number of cows on commercial dairy farms. This work has enabled him to investigate effects of nutritional and hormonal treatments on health and reproductive performance. His most notable contributions include demonstrating the effects of gossypol intake on lactation, embryo quality, and fertility of dairy cows; the effects of fatty acids on reproduction; and the development of reproductive programs to optimize embryo quality and the reproductive performance of dairy cows. Over the past decade, he has become an invaluable state, national, and international resource in the areas of dairy cattle nutrition and reproductive management. In 2005, Santos and a group of academicians and leaders in the dairy industry established the Dairy Cattle Reproduction Council with a vision to promote the development and adoption of reproductive technologies by disseminating information to dairy producers, veterinarians, farm personnel, and allied industry.

Santos has authored and coauthored 81 journal articles, 6 reviews or book chapters, 108 abstracts, and numerous popular press articles and conference proceedings. He has been an invited speaker and has delivered over 130 presentations at numerous confer- 
ences and symposia for scientific, veterinary, and producer audiences in Argentina, Brazil, Canada, Chile, Colombia, England, Hungary, Ireland, Japan, Mexico, Spain, and the USA. He has received over $\$ 1.9$ million in competitive grant support and gifts for his research program and has studied several of the important problems facing the modern dairy industry. He has demonstrated a creative approach to integrating nutrition and reproduction knowledge, specifically for evaluating factors related to postpartum health, embryonic quality, survival, and resulting fertility in lactating dairy cows. Santos has chaired 16 graduate committees including 3 $\mathrm{PhD}, 6 \mathrm{MS}$, and 7 MPVM students and has supervised 3 visiting $\mathrm{PhD}$ students. Previous recognition of his research includes the Cargill Animal Nutrition Young Scientist Award from ADSA in 2005.

\section{Citation for Arlyn Jud Heinrichs Recipient of the 2009 Pioneer Hi-Bred Forage Award}

Arlyn "Jud" Heinrichs, professor of dairy cattle nutrition in the Department of Dairy and Animal Science at The Pennsylvania State University, is the recipient of

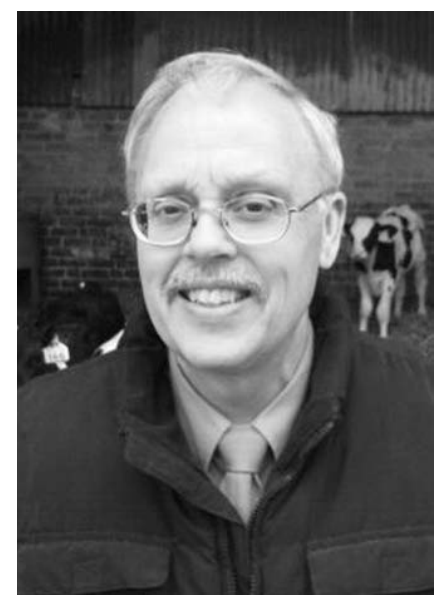
the 2009 Pioneer Hi-Bred Forage Award. Since his appointment in 1982, he has held an extension and research position at Penn State. From the very start of his career through the present, Heinrichs has worked on understanding and improving forage utilization by dairy cows and heifers. One of his first journal papers (published in 1984) was about the utilization of ammoniatreated corn silage by dairy cows, and one of his most recent journal articles (published in 2009) evaluates the effect of forage on nitrogen utilization by dairy heifers.

Many of his research and extension activities have contributed to improved utilization of forages by dairy cows and heifers; however, his single greatest impact has been via the development of the Penn State Forage and TMR Particle Size Separator. He was a co-inventor of this device, which is a scaled-down, on-farm-friendly version of the American Society of Agricultural Engineering standard and has been used in over 40 countries worldwide since its introduction in 1995. Over 4,200 Penn State Particle Separators have been sold in countries around the world. Currently, the reference describing this device is the 18th most-cited article published in the Journal of Dairy Science. Because the separator can be used on-farm, it has great value in ensuring silage is made with the correct particle size. This aids in promoting good fermentation in the silo and adequate rumination by cattle when they are fed the silage. The separator is an important tool for modifying management practices to optimize nutritional and feeding needs for dairy animals. Many of Heinrichs' recent research studies have involved using the particle separator to develop effective fiber indices for forages. The Penn State Particle Separator was updated in 2001 as a culmination of a series of lactating cow experiments. These papers have been recently published along with a variety of popular press publications related to using the improved Penn State Particle Separator. Many dairy nutritionists consider this device an invaluable tool for evaluating dairy nutrition programs on farms. In addition, it is being used widely as a research tool in a variety of dairy nutrition experiments.

Heinrichs is a leading dairy extension specialist and researcher. He has authored or coauthored 96 journal articles and hundreds of newsletter, magazine, and proceedings articles. He has organized and resourced countless outreach activities including the annual Penn State Dairy Nutrition Workshop, which has more than 400 attendees each year. During the past seven years, he has given presentations in 12 countries and 14 states on various topics. Seven students have been awarded the $\mathrm{PhD}$ degree and nine students have received an MS degree under his direction. Heinrichs's active research, extension, and teaching program has had a very positive influence on the dairy and forage industries.

\section{Citation for John Middleton \\ Recipient of the 2009 West Agro Inc. Award}

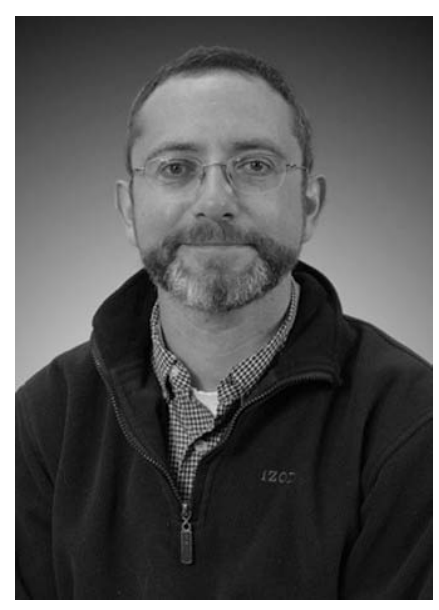

John R. Middleton, recipient of the 2009 West Agro Award, earned his BS, DVM, and PhD degrees from Washington State University and is a licensed veterinarian in Washington and Missouri. In 2001, he accepted a faculty position in the Department of Veterinary Medicine and Surgery at the University of Missouri, where he is currently an associate professor. Middleton's 


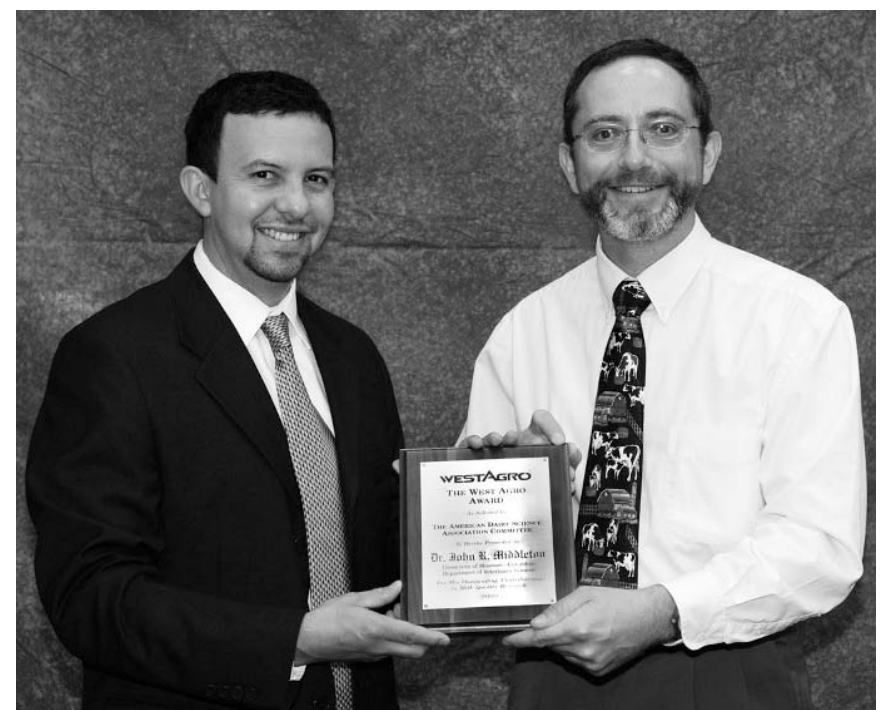

John Middleton (right) receives the 2009 West Agro Inc. Award from Mario Lopez-Benavides, donor representative (left).

productive research program has been focused on staphylococcal mastitis epidemiology, immunity, prevention, and control. This research has primarily involved vaccination and treatment of Staphylococcus aureus mastitis, molecular epidemiology of coagulase-negative staphylococcal mastitis, detection of antibiotic residues in milk, influence of $S$. aureus mastitis on serum trace mineral concentrations, and the influence of subclinical hypocalcemia at calving on postpartum health.

Middleton's research contributions have attracted collaborative efforts with US and Canadian scientists and duties with professional organizations. He serves as an external collaborator with the Canadian Bovine Mastitis Research Network, for whom he is using molecular genotyping to speciate and strain-type coagulase-negative staphylococcal isolates to enable characterization of the relationship between bacterial species, strain, intramammary infection, and inflammation. He has served as secretary, vice chair, and chairman of the Northeast Regional Multi-State Research Project NE-1028 and has been the director for Missouri since 2003. He served as chair of the Mastitis Research Workers Conference in 2005 and assisted with the development of the first combined meeting of the Mastitis Research Workers Conference and the Canadian Bovine Mastitis Research Network in Toronto, Canada, in November 2008. He is a member of the National Mastitis Council (NMC) and ADSA. Middleton has served on the NMC dairy quality assurance subcommittee since 2003 and on the NMC research committee since 2006. In 2007 and 2008, he served on the NMC annual meeting program committee and chaired a subcommittee to organize the Sunday symposium titled "Drug Use on Dairy Farms, What We All Need to Know." Middleton has also served as an ad hoc reviewer for 18 scientific journals and grant reviewer for several national and international granting agencies.

Middleton has been an excellent mentor for graduate students, veterinary students, and house officers. At the University of Missouri, he has advised or co-advised six MS students and one $\mathrm{PhD}$ student and mentored 14 residents, interns, and research fellows and 20 undergraduate research students. He has been heavily involved in clinical instruction of veterinary students and has contributed to the instruction of undergraduate and graduate students. His teaching excellence has been recognized by receipt of the Clinical Area Instructional Award in 2005, 2006, 2007, and 2008 and the Golden Aesculapius Award for Excellence in Teaching in 2008.

John Middleton has been an original and productive researcher in the field of dairy medicine and mastitis and an excellent teacher and mentor, and he is a worthy recipient of this year's West Agro Award.

\section{Citation for Jacob Green \\ Recipient of the 2009 National Milk Producers \\ Federation Graduate Student Paper Presentation Contest in Dairy Production, MS division}

Jacob Green, a MS student at the University of Missouri-Columbia, is the first place winner of the 2009 ADSA Production Division Oral Paper Competition (MS Division). Jacob obtained his BS degree from the University of Missouri-Columbia in 2007. He is cur-

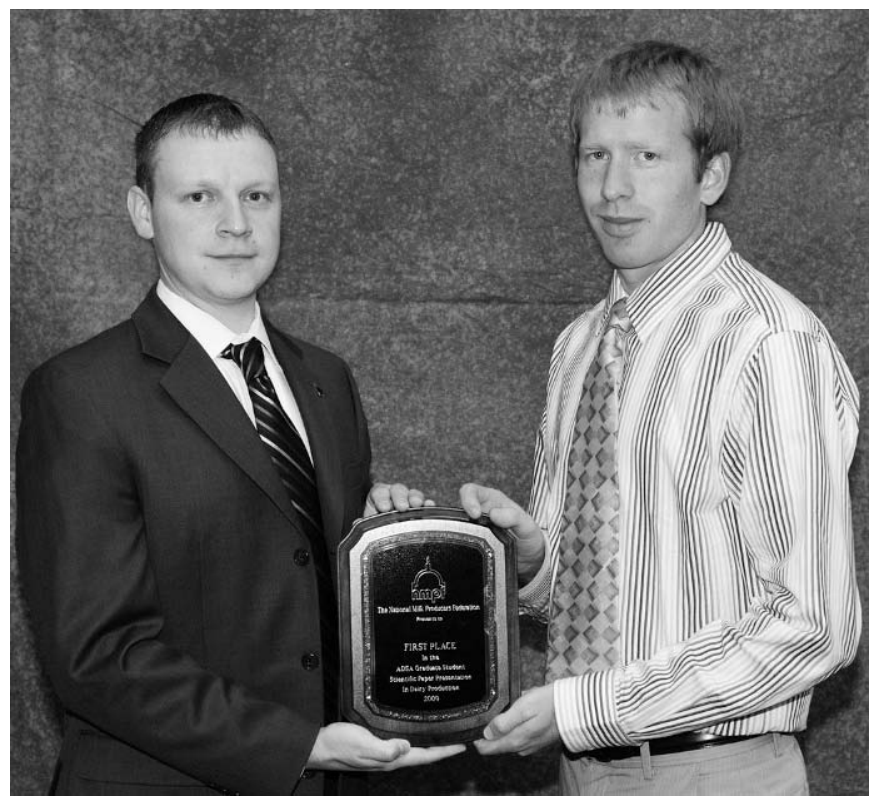

J. C. Green (right) receives the 2009 National Milk Producers Federation Graduate Student Paper Presentation Contest in Dairy Production (MS division) from Jamie Jonker, donor representative (left). 
rently working as a MS student in the laboratory of Dr. Matt Lucy at the University of Missouri-Columbia. The title of his presentation was "Accuracy of an onfarm blood test for pregnancy in dairy and beef cattle." Jacob is interested in developing new methods for early pregnancy diagnosis that can be use to improve reproductive efficiency on dairy farms.

Anna C. Denicol of the University of California-Tulare placed second, and Brittany L. Dyck of the University of Alberta placed third.

\section{Citation for Joseph McFadden \\ Recipient of the 2009 National Milk Producers \\ Federation Graduate Student Paper Presentation Contest in Dairy Production, $\mathrm{PhD}$ division}

Joseph McFadden, a PhD student at Virginia Tech, was the first place winner of the 2009 ADSA Production Division Oral Paper Competition (PhD Division). Joseph obtained his BS degree from Cornell University in 2003 and his MS degree from University of Illinois in 2006. He is currently working as a $\mathrm{PhD}$ student in the laboratory of Benjamin Corl at Virginia Tech. The title of his presentation was "Activation of AMP-activated protein kinase inhibits de novo fatty acid synthesis in bovine mammary epithelial cells." Joseph is interested in identifying molecular targets that regulate lipogenesis in the bovine mammary gland.

Heather M. White of Purdue University placed second and Nora M. Bello of Michigan State University placed third in the competition.

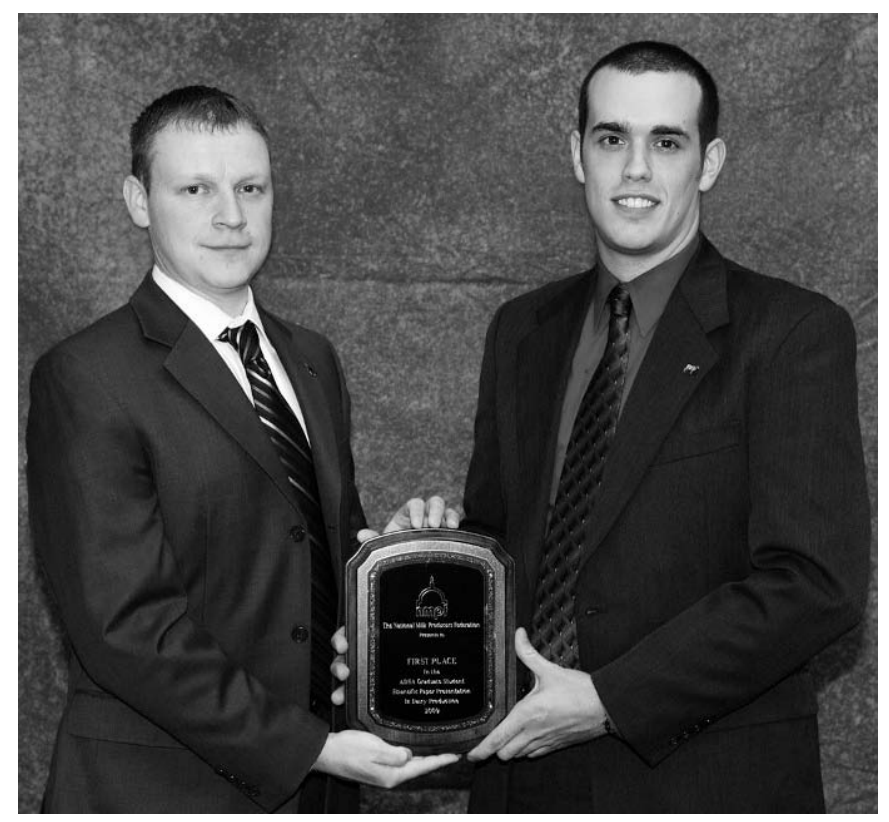

J. W. McFadden (right) receives the 2009 National Milk Producers Federation Graduate Student Paper Presentation Contest in Dairy Production (PhD division) from Jamie Jonker, donor representative (left).

\section{Citation for Steve Beckman \\ Recipient of the 2009 Dairy Management Inc. Graduate Student Paper Presentation Contest in Dairy Foods}

Steve Beckman completed his BS in food science at the University of Nebraska-Lincoln. Steve is currently an MS candidate in the Department of Food Science at Cornell University, working on the efficiency of microfiltration of skim milk using polymeric spiral-wound membranes. His presentation in the Graduate Student Paper Competition was titled "Production efficiency of a serum protein (SP) reduced micellar casein concentrate (MCC) produced with polymeric spiral-wound microfiltration (MF) membranes." Steve is a recipient of 3 scholarships (Dairy Management Inc. scholarship, Oak Smith scholarship, and Lancaster County Farm Bureau scholarship) and 2 awards (Young American award and the Eagle Scout award).

Joseph Loquasto of The Pennsylvania State University placed second and Kelsey Ryan of North Carolina State University placed third in the competition.

\section{Citation for Leane Oliveira Recipient of the 2009 Land O'Lakes, Purina Feed LLC Graduate Student Poster Contest in Dairy Production, MS division}

Leane Oliveira, an MS student at the University of Wisconsin-Madison, was the first place winner of the 2009 ADSA Production Division Poster Competition

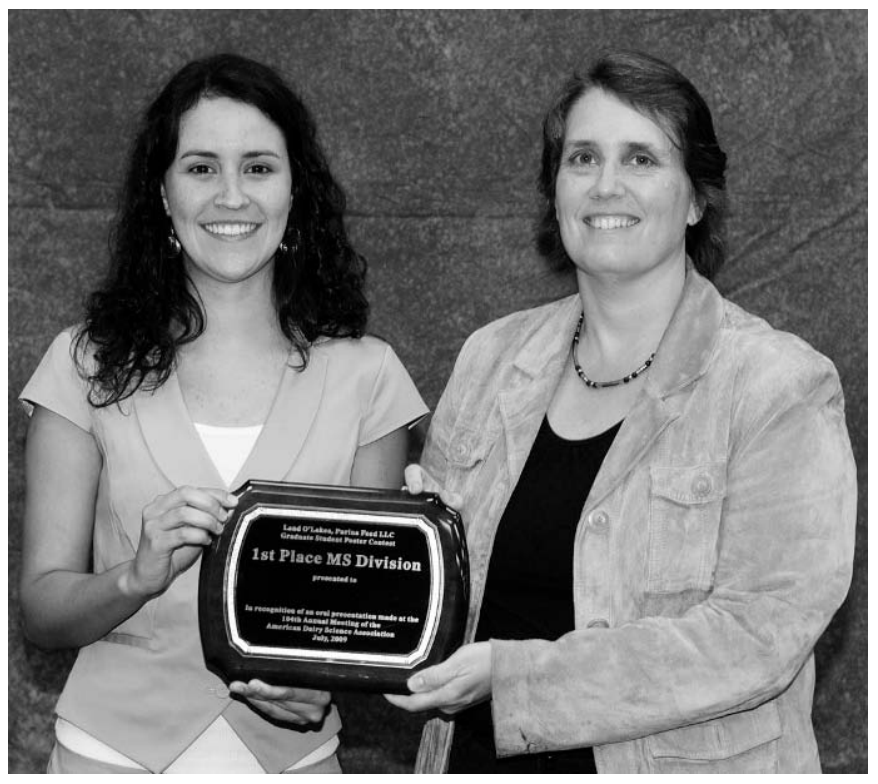

L. Oliveira (left) receives the 2009 Land O'Lakes, Purina Feed LLC Graduate Student Poster Contest in Dairy Production (MS division) from Cindie Luhman, donor representative (right). 
(MS division). Leane obtained a veterinary degree from Sao Paulo State University in Botucatu, Brazil. She is currently a MS student working in the laboratory of Pamela Ruegg at the University of Wisconsin-Madison. The title of her poster presentation was "Risk factors for multi-drug resistance of Staphylococcus aureus obtained from cases of mastitis." Leane is interested in the genetic diversity and expression of enterotoxin of staphylococcus aureus associated with bovine mastitis.

Henry A. Paz of The Ohio State University placed second, and Daniel E. Rico of The Pennsylvania State University placed third in the competition.

\section{Citation for Heather M. White Recipient of the 2009 Land O'Lakes, Purina Feed LLC Graduate Student Poster Contest in Dairy Production, PhD division}

Heather M. White, a PhD student at Purdue University, was the first-place winner of the 2009 ADSA Production Division Poster Competition (PhD division). Heather obtained a BS in biology from Saint Mary's College in Notre Dame, Indiana, and an MS in nutritional physiology from Purdue University. She is currently a $\mathrm{PhD}$ student working in the laboratory of Shawn Donkin at Purdue University. Her poster presentation was titled "Regulation of bovine pyruvate carboxylase promoters by fatty acids." Heather is interested in the role of pyruvate carboxylase in gluconeogenesis and TCA cycle carbon flux.

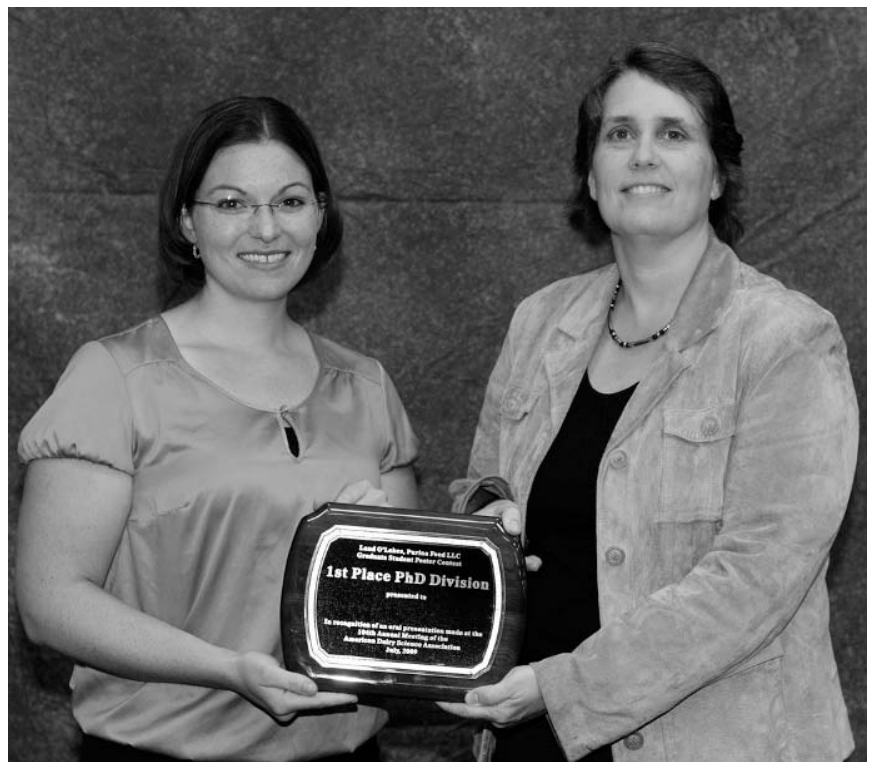

H. M. White (left) receives the 2009 Land O'Lakes, Purina Feed LLC Graduate Student Poster Contest in Dairy Production (PhD division) from Cindie Luhman, donor representative (right).
Anne M. O'Donnell of Cornell University placed second, and Ranga Appuhamy of Virginia Polytechnic Institute and State University placed third in the competition.

\section{Citation for Emily Waggoner Recipient of the 2009 Genevieve Christen Undergraduate Student Award}

Emily Waggoner is an exceptional young person who has done and will continue to do great things for the dairy industry. A recent graduate of Clemson Univer-

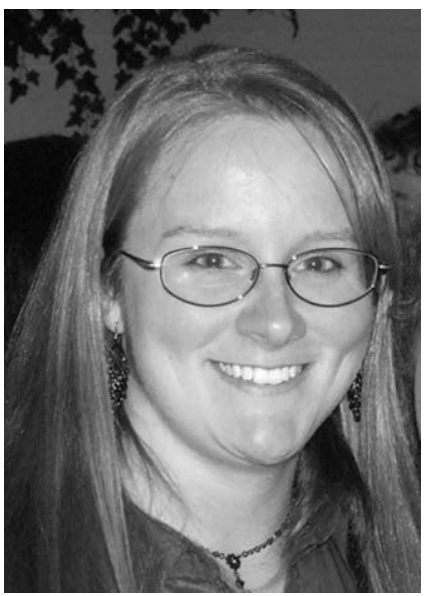
sity, Waggoner is now attending the University of Georgia College of Veterinary Medicine, focusing on production animal medicine. While at Clemson, she served as the Dairy Science Club president for three years, during which time there was exponential growth in membership and the club became an active participant in regional and national ADSA-SAD activities. At the 2008 national meetings, Waggoner won the production paper category and was elected as the 2008-2009 national ADSA-SAD President. In addition to these activities, you will find Waggoner spending every free moment as partner in the running of her family dairy operation "Kiss "em All," where she continues to hand pick, breed, raise, and show a selection of her own dairy animals. She received accolades as a member of the dairy cattle evaluation team to be included in the top 25 at the World Dairy Expo collegiate judging contest and competed on the first Clemson dairy challenge team. To make her days even busier, she has just completed the running of her own reproductive research project in dairy animals with funding received from the SC Life Undergraduate Research Program and is listed as coauthor on three research abstracts this year. In preparation for her career aspirations, she also volunteers at a local veterinary hospital. It is truly noteworthy that she does all of this and more while maintaining a perfect academic record. Waggoner is an inspiration to others and accepts this role with absolute humbleness. She aspires to do so much in and out of the dairy industry in her future. While in veterinary school, Waggoner plans on continuing to expand and improve her herd and assist with the maintenance of the farm. If you were ever to ask Waggoner about her 


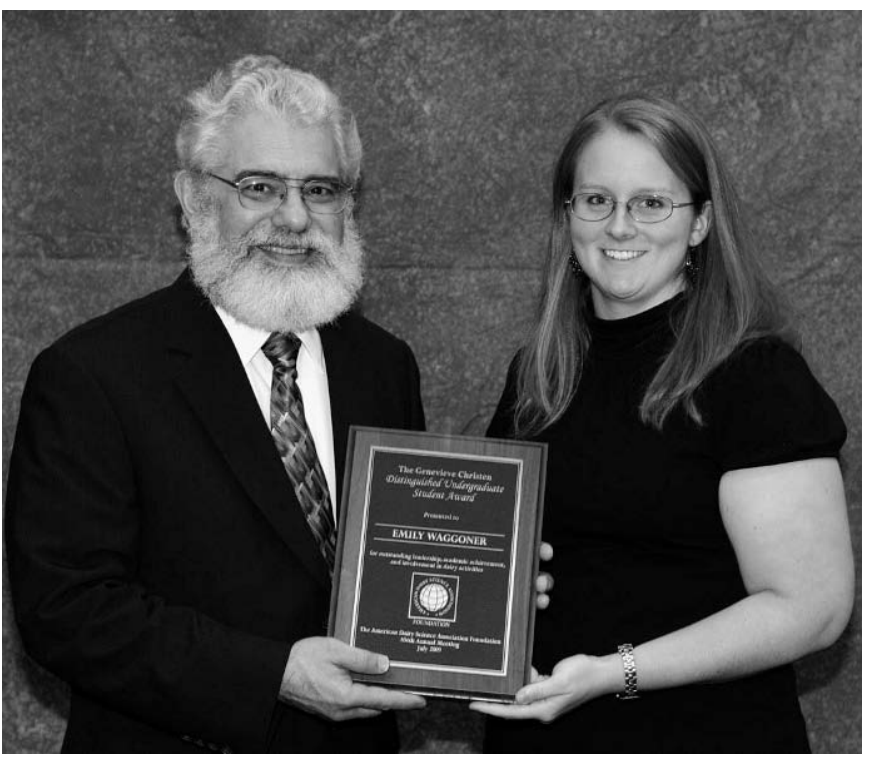

Emily Waggoner (right) receives the 2009 Genevieve Christen Undergraduate Student Award from Dave Barbano, ADSA Foundation Chair (left).

favorite moment in life, it would be some experience with one of her dairy animals, and if you were ever to ask her what would be the best thing that could happen to her, it would involve something with the dairy cow. She is a person capable of doing anything that she sets her mind to, and we are so lucky that her heart leads her to the dairy industry. Amazing would be the only way to describe all that she has accomplished and aspires to accomplish. Her zest for life and the dairy cow has fashioned new dairy enthusiasts and revitalized the passion in others. She exemplifies the leadership, scholarship, and service to the dairy industry that the Genevieve Christen Award represents. Emily Waggoner is honored by and deserving of the 2009 Genevieve Christen Award.

\section{Citation for Lance Baumgard Recipient of the 2009 ADSA Foundation Scholar Award in Production}

Lance Baumgard's nutritional physiology research program primarily concentrates on lipid metabolism and nutrient partitioning with a focus on energy utilization in lactating dairy cows. He has evaluated and attempted to manipulate milk synthesis during this lactation period by using conjugated linoleic acid (CLA), direct-fed microbials, and altered milking frequency. This period of the lactation cycle is associated with a plethora of metabolic and reproductive problems and, thus, is a costly issue in both American and global agriculture. These problems are related to/associated with the negative energy balance that most mammalian mothers experience after giving birth. Scientists have traditionally tried to alleviate this energy balance problem by feeding grains and fats (energy-dense feeds), but

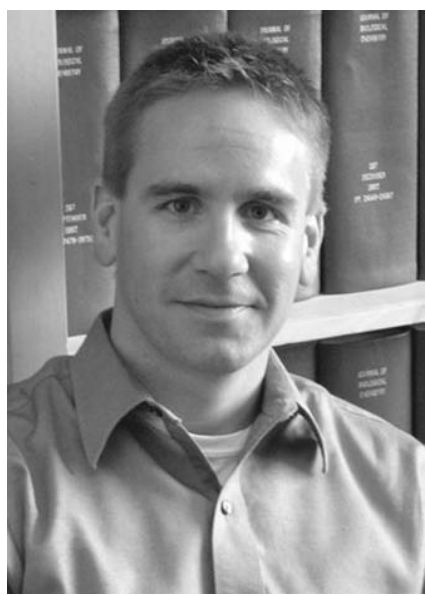
the problem is still a significant issue in the dairy industry. Baumgard's group has taken a novel approach via reducing milk fat synthesis. He has conducted experiments in both TMR- and pasturefed cows and for the first time has demonstrated that energy balance (and energy balance related issues) can be markedly (>4 Mcal) improved. An interesting academic argument (with direct industry implications) that has been revitalized by his work is whether or not a lack of energy limits milk yield in early lactation. These experiments are valuable contributions to both the scientific literature and the dairy industry and have added to our insight into the energypartitioning mechanisms in early-lactating animals.

A recent area of research that Baumgard has focused much of his attention on is the postabsorptive metabolic adaptations that occur in heat-stressed lactating dairy cows. His group has recently discovered a number of novel physiological changes that occur with the onset of heat stress. For example, he has reported that heat-stressed cows do not mobilize adipose tissue as

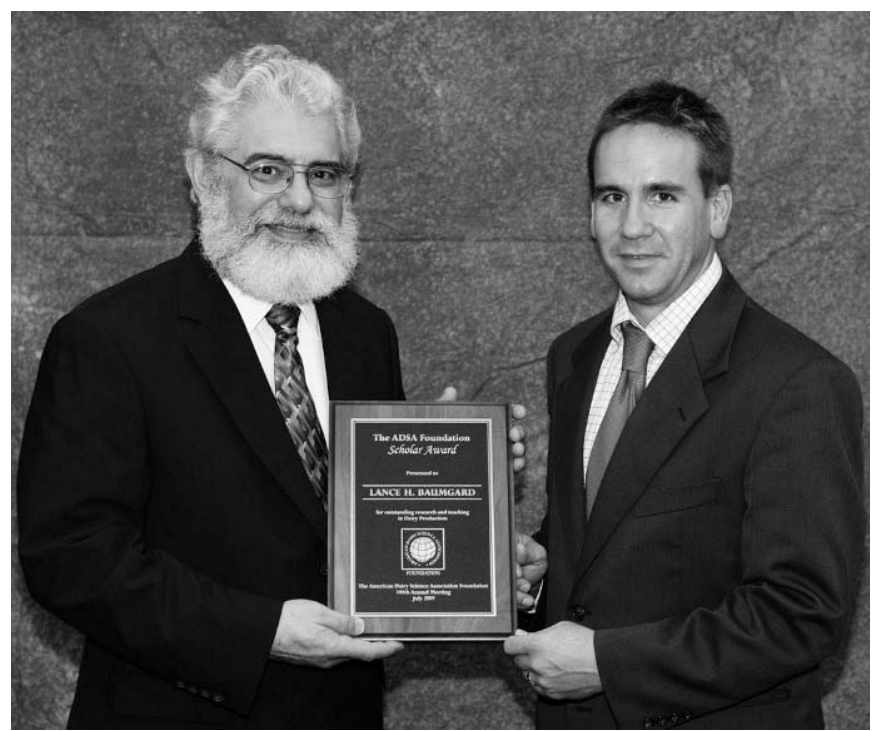

Lance Baumgard (right) receives the 2009 ADSA Foundation Scholar Award in Dairy Production from Dave Barbano, ADSA Foundation Chair (left). 
their energetic state would predict. Furthermore, utilizing a number of classic physiological techniques (e.g., hormonal and metabolic challenges, labeled glucose infusion, tissue biopsies, hyperinsulinemic-euglycemic clamps), he has shown that a variety of carbohydrate and lipid metabolism changes occur in a coordinated effort to minimize the production of metabolic heat, and this can largely be explained by increased systemic insulin action and an increased pancreatic insulin secretion. As a consequence, despite the heat-stressed cow entering into negative energy balance, she fails to enlist glucose-sparing mechanisms and systemic tissues begin to utilize glucose at an increased rate. This heatinduced phenomenon results in less glucose available for mammary lactose synthesis. Therefore, this altered nutrient partitioning explains why milk yield decreases much more than would be predicted by nutrient intake (shown for the first time by his group). Apart from the obvious economic implications of this research, the heat-stressed cow provides a unique model to expand on and reevaluate established biological dogmas. For example, it has long been thought that energy balance closely parallels circulating nonesterified fatty acids (products of adipose tissue breakdown). However, Baumgard's recent data clearly indicate that this is not the case in heat-stressed cows.

\section{Citation for Michael Hutjens Recipient of the 2009 ADSA Award of Honor}

Michael Hutjens was raised on a Holstein dairy farm near Green Bay, Wisconsin. His BS degree (1967), MS degree (1969), and PhD degree (1971) were com-

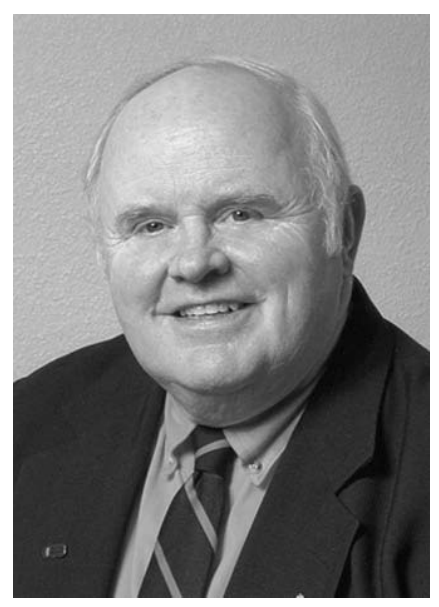
pleted at the University of Wisconsin, Madison. His joint doctorate degree was in dairy science and nutritional science with a minor in biochemistry. Hutjens received the Ralston-Purina National Fellowship and first place in the ADSA graduate paper production award.

Hutjens has served ADSA as a member of the board of directors, vice president, president, and past president; served on the ADSA Foundation auction committee; and served on numerous ADSA committees and in key leadership roles in the Production Division throughout his 41-year membership. Hutjens provided key leadership on the

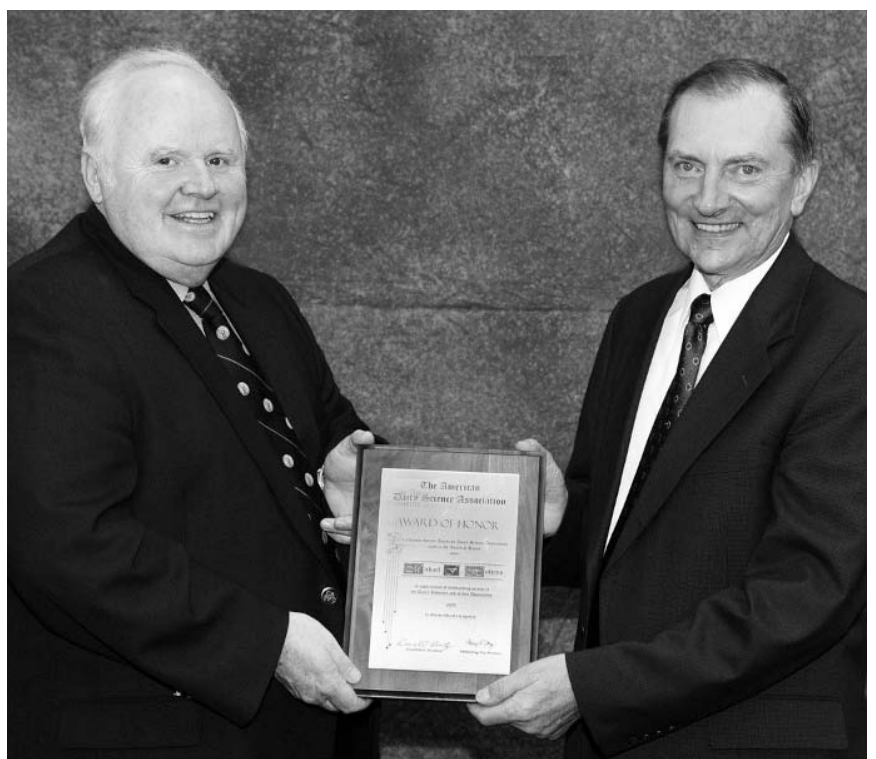

Michael Hutjens (left) receives the 2009 ADSA Award of Honor from Donald Beitz, ADSA President (right).

FASS board of directors during a period of restructuring, resulting in FASS regaining a solid financial foundation. His service to the Midwest ADSA has included the positions of president, program chair, and member of the extension committee. He received three awards from ADSA (Undergraduate Teaching Purina Award, Applied Nutrition Award, and DeLaval Extension Worker Award) and was selected as a Fellow in 2008.

From 1971 to 1979, Hutjens was extension dairy specialist at the University of Minnesota, where he coached the national champion team in 1978. Since 1979, he has been a member of the University of Illinois Dairy and Animal Sciences Departments as extension dairy specialist. He speaks annually at 110 programs at conferences in 46 states, South Africa, Australia, Brazil, France, Argentina, Czech Republic, Ireland, Italy, Japan, Korea, Mexico, New Zealand, Puerto Rico, Spain, China, Zimbabwe, and nine Canadian provinces. Hutjens writes feed columns for Hoard's Dairyman, Dairy Today, Dairy Japan, and Dairy Herd Management. In 1989, he coauthored a textbook titled Principles of Dairy Science. Hutjens has authored four Hoard's Dairyman Technical Bulletins (Feed Guide, Transition Cow Management, Forages, and Feeding Systems). He teaches three campus dairy classes and three Internet-based courses. He was an official judge of the Hoard's Dairyman Cow Contest, World Dairy Expo, and 16 state fairs.

Award recognitions besides several ADSA awards include the University of Illinois Campus Service Award, Young Extension Scientist (College of Agriculture, Illinois), Carlisle Extension Award (Animal Science 
Department), Midwest Regional Young Extension Award (sponsored by the American Society of Animal Science), Paul A. Funk Outstanding Faculty Award (College of Agriculture), Outstanding Extramural Instructor (University-wide award) in 1993 and 2000, two citations from the Minnesota Board of Regents, Purebred Dairy Cattle Association 1990 Superior Service Award, 1990 Dairy Person of the Year (Illinois Milk Producers Association), and Minnesota Holstein Association's Person of the Year Award. In 2008, he was select Industry Person of the Year by the World Dairy Expo for his contributions to the industry.

Hutjens resides in Savoy, Illinois, with his wife, Carol, and five children (three sons and two daughters) and five grandchildren. He served six years in the U.S. Army Reserve, ending as a specialist five with an honorable discharge.

\section{Citation for Stanley Gilliland Recipient of the 2009 ADSA Distinguished Service Award}

Stanley E. Gilliland has provided distinguished service resulting in profound effects on the animal and food industries. He is recognized internationally for his

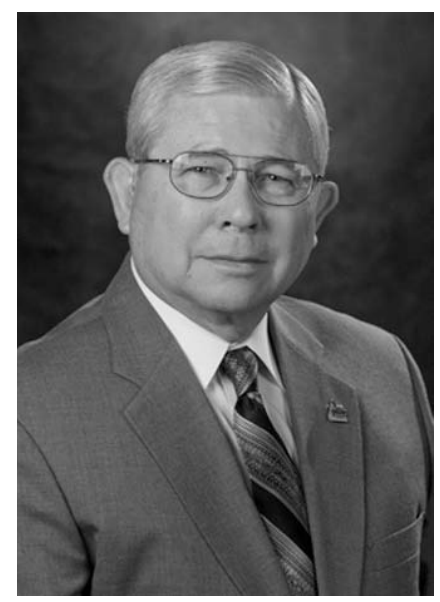

pioneering research on the use of lactobacilli as probiotics in enhancing human health and increasing animal growth and feed efficiency. He was a major player on the team at North Carolina State University that conducted research leading to the commercialization of nonfermented acidophilus milk (sweet acidophilus milk) in 1975 . This product has provided millions of people with this organism without the undesirable taste associated with fermented acidophilus milk. This concept of adding a probiotic culture of Lactobacillus acidophilus to nonfermented milk has been used throughout the world to develop dairy products such as yogurt to which desirable probiotic cultures are incorporated today.
Since that time, his research has focused heavily on the development and function of lactobacilli as probiotics for both humans and livestock. These organisms can provide numerous potential health and nutritional benefits, including control of intestinal pathogens, improved nutrient utilization, and control of serum cholesterol levels.

Gilliland was the first to establish that consumption of milk containing L. acidophilus or yogurt containing viable starter cultures by lactose maldigestors resulted in improvement of lactose utilization, thus enabling them to consume dairy products. He has shown that inclusion of a culture of $L$. acidophilus selected for the ability to deconjugate bile acids and to assimilate cholesterol during growth in the diet could reduce serum cholesterol levels.

Gilliland has made significant contributions to the control of food-borne pathogens by his studies on Escherichia coli O157:H7. His research related to the role of probiotics in food safety has led to the isolation and development of strains of L. acidophilus from cattle that have the potential to inhibit the growth of E. coli O157:H7. The efficacy of a culture developed by Gilliland has been tested in studies involving cattle. Results have shown that the inclusion of this organism in cattle diets has resulted in significant reduction (as much as 30\%) in the incidence of E. coli O157:H7. In addition, the product also improves feed efficiency in beef cattle and increases milk production in dairy cattle. This probiotic culture is currently licensed to a commercial company and earns more royalties than any other intellectual property at Oklahoma State University. Gilliland has used that royalty income to augment his research on probiotics and the research programs of virtually all the faculty in Animal Science and Food Science at Oklahoma State University by purchasing equipment for their labs and supporting graduate assistants for their research programs.

Gilliland has served ADSA as board member, vice president, and president. He has also served the ADSA Foundation as board member, chairman, and secretary. He represented ADSA as president of FASFAS (the predecessor of FASS). He has served on the Discover Conference steering committee and has chaired or cochaired three separate Discover Conferences. He served as senior editor for the Journal of Dairy Science. 